\title{
Spiroplasma melliferum, a New Species from the Honeybee (Apis mellifera)
} T. B. CLARK,,${ }^{1 \dagger}$ R. F. WHITCOMB,${ }^{1 *}$ J. G. TULLY,${ }^{2}$ C. MOUCHES,${ }^{3}$ C. SAILLARD,${ }^{3}$ J. M. BOVÉ,${ }^{3}$ H.
WRÓBLEWSKI,${ }^{4}$ P. CARLE, ${ }^{3}$ D. L. ROSE, ${ }^{2}$ R. B. HENEGAR, ${ }^{1}$ AND D. L. WILLIAMSON

Insect Pathology Laboratory, Plant Protection Institute, Beltsville Agricultural Research Center, United States Department of Agriculture, Beltsville, Maryland 20705'; Mycoplasma Section, Laboratory of Molecular Microbiology, National Institute of Allergy and Infectious Diseases, Frederick Cancer Research Center, Frederick, Maryland $2170{ }^{2}$; Laboratoire de Biologie Cellulaire et Moleculaire, Institut National de la Recherche Agronomique et Université de Bordeaux II, Domaine de la Grande Ferrade, F-33140, Pont de la Maye, France ${ }^{3}$; Laboratoire de Microbiologie Fondamentale et Appliquée, Université de Rennes, I, Campus de Beaulieu, F-35042, Rennes Cédex, France ${ }^{4}$; and Department of Anatomical Sciences, State University of New York, Stony Brook, New York 11794

\begin{abstract}
Twenty-eight strains of spiroplasma subgroup I-2 isolated from insects and flower surfaces were similar in their serological properties. Strain $\mathrm{BC}-3^{\mathrm{T}}(\mathrm{T}=$ type strain), which was isolated from the honeybee, was chosen as a representative of this cluster and was characterized according to accepted standards. This strain and other strains of the cluster entered the hemocoel of their insect hosts after per os acquisition, caused pathology in various tissues, and reduced adult longevity. Growth in SM-1 or M1D medium occurred at 20 to $37^{\circ} \mathrm{C}$, with optimum growth at about 32 to $35^{\circ} \mathrm{C}$. Cholesterol was required for growth. Glucose, fructose, and other carbohydrates were fermented, and arginine was catabolized. Seventeen strains, including strain $\mathrm{BC}^{\mathrm{C}} \mathbf{3}^{\mathrm{T}}$, reacted with considerable homogeneity in deformation tests and were completely separable from strains of subgroup I-1 (Spiroplasma citri) and subgroup I-3 (corn stunt spiroplasma). A group of five subgroup I-2 strains showed homogeneity upon one-dimensional polyacrylamide gel electrophoresis of cell proteins. Strain BC-3 ${ }^{T}$ was also serologically distinct from subgroups I-4 through I-8; from Spiroplasma floricola, Spiroplasma apis, and Spiroplasma mirum; and from representative strains of spiroplasma groups II and VI through XI. Previously published studies on strain $B C-3^{T}$ and related strains demonstrated that (i) these organisms comprise a unique subgroup of the $S$. citri complex (group I); (ii) deoxyribonucleic acid-deoxyribonucleic acid homologies between strain $\mathrm{BC}-3^{\mathrm{T}}$ and strains of other group I subgroups do not exceed $70 \%$; (iii) the patterns of protein sharing among group I strains revealed by two-dimensional polyacrylamide gel electrophoresis support molecular genetic indications of partial relatedness; (iv) the EcoRI restriction endonuclease patterns of deoxyribonucleic acids from strain $\mathrm{BC} \cdot 3^{\mathrm{T}}$ and serologically related strains show close relatedness; (v) sequencing of $5 \mathrm{~S}$ ribosomal ribonucleic acid suggests some degree of relatedness with all organisms now classified in the Mollicutes; (vi) strain $\mathrm{BC}-3^{\mathrm{T}}$ is capable of viscotactic and chemotactic responses; (vii) strain $B C-3^{\mathrm{T}}$ possesses fibrils that may mediate various types of motility; and (viii) a lytic virus (SpV4) isolated from Spiroplasma sp. strain B63 (a representative of subgroup I-2) is morphologically and genomically distinct from other spiroplasma viruses and forms plaques only on lawns of subgroup I-2 spiroplasmas. Previous work on strain AS 576, another member of subgroup I-2, demonstrated (i) a viscotactic response, (ii) moderate sensitivity to osmotic environments, (iii) susceptibility to tetracycline and aminoglycoside antibiotics, (iv) growth in a relatively simple, chemically defined medium, (v) nutritional utilization patterns in defined medium, and (vi) a genome molecular weight of $10^{9}$. On the basis of our new findings and the previously described properties of strain $\mathrm{BC}-3^{\mathrm{T}}$ and related subgroup $\mathrm{I}-2$ strains, we propose that spiroplasma strains with the characteristics described here be classified as a new species, Spiroplasma melliferum. Strain BC-3, the type strain, has been deposited in the American Type Culture Collection as strain ATCC 33219.
\end{abstract}

In 1976, in the course of an examination of honeybees for pathogenic microorganisms, a helical wall-less procaryote was found at high frequencies in bees from hives of the Bioenvironmental Bee Laboratory in Beltsville, Md. (16). This organism, which was isolated in modified Singh mosquito tissue culture medium (GIBCO Laboratories, Grand Island, N.Y.) and was identified as a member of the genus Spiroplasma, was the first cultivable spiroplasma found to be confined to insects. Although strain $\mathrm{BC}-3^{\mathrm{T}}$ ( $\mathrm{T}=$ type strain) of this organism has since been used as a generic representative more frequently than any other strain except Spiroplasma citri strain $\mathrm{R} 8 \mathrm{~A} 2^{\mathrm{T}}$, the precise taxonomic placement of strain $\mathrm{BC}-3^{\mathrm{T}}$ and similar strains has been held in abeyance. This circumstance arose in part as a result of

\footnotetext{
* Corresponding author.

$\dagger$ Deceased.
}

substantial serological cross-reactions among strain $\mathrm{BC}-3^{\mathrm{T}}$, strain $\mathrm{R} 8 \mathrm{~A} 2^{\mathrm{T}}$ and other strains of $S$. citri, and strains of the corn stunt spiroplasma $(29,94,105)$. Subsequently, heterologous crosses were also demonstrated between strain $\mathrm{BC}-3^{\mathrm{T}}$ and four other members of the $S$. citri complex (93). These studies eventually led to the proposal of a group (group I) of spiroplasmas that is now considered to be subdivided into eight subgroups $(5,74,96)$. Strain $\mathrm{BC}-3^{\mathrm{T}}$ and similar strains are classified as subgroup I-2 in this classification, which was first proposed by Junca et al. in 1980 and was recently revised $(47,93,94)$.

Elevation of the group I subgroups (other than the type species $S$. citri) to species status was postponed, pending clarification of the interrelationships among subgroup members. In studies directed to this problem, subgroup I-2 strains have been compared extensively with other group I strains. For example, reaction values of 52 to $64 \%$ were observed in 
TABLE 1. Strains belonging to subgroups $I-1, I-2$, and I-3

\begin{tabular}{|c|c|c|c|}
\hline Strain & Host & $\begin{array}{c}\text { Geographic } \\
\text { origin }\end{array}$ & $\begin{array}{l}\text { Reference or } \\
\text { source }\end{array}$ \\
\hline \multicolumn{4}{|c|}{ Subgroup I-1 (S. citri) } \\
\hline $\mathrm{R} 8 \mathrm{~A} 2^{\mathrm{T}}$ & Citrus & Morocco & 71 \\
\hline C189 & Citrus & California & 39 \\
\hline Israel & Citrus & Israel & M. Daniels ${ }^{a}$ \\
\hline ASP-1 & Citrus & Israel & 83 \\
\hline Iran & Citrus & Iran & P. Saglio ${ }^{a}$ \\
\hline Algeria & Citrus & Algeria & P. Saglio ${ }^{a}$ \\
\hline SCC & Circulifer & California & P. Saglio ${ }^{a}$ \\
\hline Aceratagallia & Aceratagallia & California & M. El-Bolok ${ }^{b}$ \\
\hline CB-1 & Circulifer & California & M. El-Bolok ${ }^{b}$ \\
\hline B106 & Citrus & California & M. El-Bolok ${ }^{b}$ \\
\hline
\end{tabular}

Subgroup I-2

(honeybee

spiroplasmas)

AS 576

R670

R647

$\mathrm{KC}-3$

B29

B63

F316

B88

B1707

G-1

BW

SB-1

SB-2

BC-6

AA-1

AA-2

BI-2

BU-1

BC-4

AS-3

BU-2

BC-5

BF-1

OC-3

BP-1

TT-15

Subgroup 1-3 (corn

stunt spiroplasmas)

E275

I-747

B655

B652

B647

CSEE1

CSEE2

Miss E

CRL

Honeybee

Honeybee

Flowers

Flowers

Honeybee

Honeybee

Honeybee

Flowers

Honeybee

Honeybee

Flowers

Flowers

Andrenid

Andrenid

Honeybee

Anthophora abrupta

Anthophora abrupta

Bombus impatiens

Honeybee

Honeybee

Robber fly

(Asilidae)

Honeybee

Honeybee

Butterfly

Osmia

cornifrons

Bombus penn- Maryland T. B. Clark ${ }^{a}$ sylvanicus

Flowers

California 66

Corn

Corn

Corn

Corn

Corn

Exitianus

Exitianus

Corn

Corn

${ }^{a}$ Unpublished data.

${ }^{b}$ Ph.D. thesis, University of Cairo, Giza, Egypt, 1981.

reciprocal deoxyribonucleic acid (DNA) hybridization tests of strain BC-3 ${ }^{\mathrm{T}}$ with strain $\mathrm{R} 8 \mathrm{~A} 2^{\mathrm{T}}(6,7,47,48)$; values of 48 to $49 \%$ were obtained with the corn stunt spiroplasma (subgroup I-3), and values of 19 to $21 \%$ were obtained with strain $277 \mathrm{~F}$ (subgroup I-4). When a labeled DNA probe from strain P40 (subgroup I-8) was tested against strain BC- ${ }^{\mathrm{T}}$, a value of $50 \%$ was obtained (74). The levels of reciprocal DNA homology of strain $\mathrm{BC}-3^{\mathrm{T}}$ with other group I strains were less than the level observed with $S$. citri (7). Similarly, one-dimensional (24) and two-dimensional $(5,62,63)$ polyacrylamide gel electrophoresis (PAGE) of cell proteins indicated that strain $\mathrm{BC}-3^{\mathrm{T}}$ shared some proteins with other group I strains but possessed a majority of proteins that had either completely different electrophoretic mobilities (unique proteins) or mobilities that differed somewhat from those of similar proteins in members of other subgroups (homologous proteins.) Also, strain $\mathrm{BC}-3^{\mathrm{T}}$ has been used widely in serological studies $(2,3,29,93,94,96,97,101,102,105)$; the results of all of these studies were consistent with the results of molecular genetic studies in that they indicated that there is partial, but limited, relatedness among the eight subgroups of the group I complex.

The taxonomic difficulties presented by the partially related group I strains were discussed at length by the International Committee on Systematic Bacteriology Subcommittee on the Taxonomy of Mollicutes (43-45). A conservative approach to taxonomic description was recommended, pending the results of further exploration of insects and plants for spiroplasmas and the ensuing comparative studies with these isolates. In 1980, Davis and Lee proposed (28) that subgroup I-2 strains and many other strains of certain serogroups other than group I could be promoted to species status because they are serologically distinguishable. While disagreeing strongly with some aspects of this proposal, the Subcommittee proposed (43) in 1982 that subgroups may be elevated to species status under certain conditions. These conditions were as follows: (i) all steps required in the minimal-standards document (42) must be fulfilled; (ii) the levels of DNA-DNA homology between the candidate subgroup and all other subgroups must be demonstrated to be less than $70 \%$; (iii) the ecology of the organism must be studied, and principal hosts or alternate hosts or both must be identified; (iv) the subgroup should be of importance to agriculture or public health or as a basic microbiological model; and (v) the subgroup should be shown to consist of a cluster of homogeneous strains isolated from as many different circumstances as possible. Strain homogeneity should be assessed by techniques such as serology and PAGE. This recommendation was prompted by demonstration of clusters of organisms with relative genotypic homogeneity in several mollicute species (68). Whether a particular data set fulfilled these conditions was left to the judgment of referees and editors.

In this report, we summarize experimental evidence that strain $\mathrm{BC}-3^{\mathrm{T}}$ and related strains represent a cluster of spiroplasmas for which the species requirements have been fulfilled, with respect to both the Subcommittee proposal for elevation of subgroups to species (43) and the minimal standards for mollicute species descriptions proposed in 1979 by the Subcommittee (42). Therefore, we formally propose that strain $\mathrm{BC}-3^{\mathrm{T}}$ and related strains be recognized as a new species in the genus Spiroplasma.

\section{MATERIALS AND METHODS}

Origin of isolates. A total of 28 isolates of spiroplasma subgroup I-2, 10 isolates of $S$. citri (subgroup I-1), and 10 isolates of the corn stunt spiroplasma (subgroup I-3) were examined serologically. The sources of these isolates are shown in Table 1. Strain BC-3 ${ }^{\mathrm{T}}$ was isolated in SM-1 medium 
on 5 May 1976 from the hemolymph of a honeybee from the hives of the Bioenvironmental Bee Laboratory at Beltsville, $\mathrm{Md}$. This isolate was triply cloned and was chosen as the representative of subgroup I-2. Other spiroplasmas were compared with strain $\mathrm{BC}-3^{\mathrm{T}}$. These included tick strain $277 \mathrm{~F}$ (= ATCC 29761 ; subgroup I-4 [9, 77]), strain LB-12 (= ATCC 33649; subgroup I-5 [49]), Maryland flower spiroplasma strain M55 (= ATCC 33502; subgroup I-6 [96]), Cocos spiroplasma strain N525 (= ATCC 33287; subgroup I-7 [31]), strain P40 (subgroup I-8) from Syrian Catharanthus (Vinca) (74), noncultivable strain WSRO of the Drosophila sex ratio organism (group II [100]), Spiroplasma floricola strain OBMG (= ATCC 33221; group III [17]) Spiroplasma apis strain B31 ${ }^{\mathrm{T}}\left(=\mathrm{ATCC} 33834^{\mathrm{T}}\right.$; group IV [59, 66], S. apis strain PPS1 (= ATCC 33450; group IV [56], Spiroplasma mirum strain $\mathrm{SMCA}^{\mathrm{T}}$ (= ATCC 29335; group V [89], Ixodes spiroplasma strain Y32 (= ATCC 33835; group VI [86], Monobia spiroplasma strain MQ-1 (= ATCC 33825; group VII [18]), syrphid spiroplasma strain EA-1 (= ATCC 33826; group VIII [18]), Cotinus spiroplasma strain CN-5 (= ATCC 33827; group IX [20]), Aedes strain AES-1 (group X [96]), and Monobia spiroplasma strain MQ-4 (group XI [93]).

Culture media and cultivation procedures. Strain $\mathrm{BC}-3^{\mathrm{T}}$ and all subgroup I-2 strains could be cultivated in M1D medium (95). This formulation was similar to M1 (104) and M1A (46) media, except that fresh yeast extract was omitted. Strain BC $-3^{\mathrm{T}}$ and many other isolates of subgroup I-2 were first cultivated in a modification (SM-1 medium [92]) of Singh mosquito tissue culture medium (GIBCO). Primary isolation of strain $\mathrm{BC}-3^{\mathrm{T}}$ was accomplished by adding $3 \mu \mathrm{l}$ of hemolymph to $1 \mathrm{ml}$ of liquid medium, followed by incubation at $30^{\circ} \mathrm{C}$. The techniques used for isolation of spiroplasmas from honeybees have been described previously (55). For maintenance of the organisms, cultures were passed at intervals of 1 or 2 days by using $10 \%$ inocula added to fresh media. All subgroup I-2 strains tested, including strain $\mathrm{BC}-3^{\mathrm{T}}$, could be adapted to conventional mycoplasma medium containing $20 \%$ horse serum (32).

Agar colonies of strain $\mathrm{BC}-3^{\mathrm{T}}$ and other subgroup I-2 spiroplasmas were obtained on either SP-4 medium or serum fraction broth base containing 2.25\% Noble agar (Difco Laboratories, Detroit, Mich.) ("hard" agar). Most other spiroplasmas were grown on solid media prepared from BSR (6) or M1A broth (using $0.8 \%$ Noble agar) or from SP-4 broth medium (using $2.25 \%$ Noble agar).

Most spiroplasmas used in our comparative studies were grown in M1D medium. However, the corn stunt spiroplasma strains were grown preferentially in M1A medium $(46,104)$, and $S$. mirum and strain Y32 were cultivated in SP-4 medium (88).

Filtration studies. An M1D broth culture of strain BC- $3^{\mathrm{T}}$ that had been incubated for 1 day at $30^{\circ} \mathrm{C}$ was passed through a series of membrane filters with graded pore diameters ( 450 , 300 , and $220 \mathrm{~nm}$ ) by using a hypodermic syringe and minimum hand pressure. Each filtrate was diluted in a series of 10 -fold dilutions in $1 \%$ serum fraction medium supplemented with glucose, and all tubes were incubated at $30^{\circ} \mathrm{C}$. After 7 days, the tubes were examined for growth, and the color change and turbidity were recorded. The passage of strain $\mathrm{BC}-3^{\mathrm{T}}$ through the various filters was assessed by identifying the last dilution tube that showed growth of helical cells and a color change. The results were expressed in color-changing units (CCU) per milliliter.

Morphology. Cultures of strain $\mathrm{BC}-3^{\mathrm{T}}$ were routinely monitored by dark-field microscopy. For electron microscopy, all tissues to be examined were fixed for $2 \mathrm{~h}$ in $2.5 \%$ glutaraldehyde in phosphate buffer ( $\mathrm{pH} 7.3$ ) supplemented with $0.25 \mathrm{M}$ sucrose, postfixed in Palade buffered $1 \%$ osmium tetroxide for $2 \mathrm{~h}$, dehydrated in acetone, and embedded in Spurr low-viscosity embedding medium.

Temperature requirements. Temperature requirements were determined by inoculating M1D medium with strain $\mathrm{BC}-3^{\mathrm{T}}$ to give about $10^{6} \mathrm{CCU} / \mathrm{ml}$ and incubating the cultures at $20,25,30,32$, and $37^{\circ} \mathrm{C}$. At subsequent intervals, growth was assessed by titration in a series of 10 -fold dilution tubes. Titers were expressed as numbers of CCU (reciprocals of endpoints in the 10 -fold dilution series) per milliliter.

Sterol requirement. The growth response to cholesterol was determined by the direct broth culture method (67).

Biochemical tests. A simplified variation of conventional mycoplasma medium, in which the serum was replaced by $1 \%$ bovine serum fraction, was used for substrate utilization tests. This medium contained $21 \mathrm{~g}$ of mycoplasma broth base (BBL Microbiology Systems, Cockeysville, Md.) per liter, $10 \%$ fresh yeast extract (Flow Laboratories, Rockville, Md), and $1 \%$ bovine PPLO serum fraction (Difco) (71). Strain $\mathrm{BC}-3^{\mathrm{T}}$ grew rapidly in this medium, producing an indicator change as the medium acidified. Utilization of substrates was assessed by observing indicator changes that occurred before changes in control tubes that had received an equal amount of inoculum but did not contain a test substrate. The medium variations used were serum fraction base medium (i) without arginine or glucose or with (ii) $1 \%$ glucose, (iii) $0.2 \%$ arginine, (iv) $1 \%$ glucose and $0.2 \%$ arginine, (v) $1 \%$ urea, or (vi) $1 \%$ glucose and $1 \%$ urea. Strain $\mathrm{BC}-3^{\mathrm{T}}$ was inoculated into each medium, and three 10 -fold dilutions were prepared. All tubes were incubated at $30^{\circ} \mathrm{C}$ and observed daily for indicator change.

Additional tests were performed on 19 subgroup I-2 strains to assess their ability to ferment glucose and catabolize arginine. These tests were performed in serum fraction medium in which the fresh yeast extract concentration was reduced to $2.5 \%$.

Phosphatase activity, tetrazolium reduction, hemadsorption, and digitonin susceptibility tests were performed on solid medium (serum fraction broth containing $2.25 \%$ Noble agar) by previously described techniques $(1,8,35,37,54)$.

Membrane protein. Membrane protein was purified from honey bee spiroplasma strain B88 by procedures described previously (107). Antibodies against membranes and the spiralin homolog from strain B88 were elicited in rabbits by subcutaneous inoculations with Freund adjuvant as described previously (108).

Serological tests. Hyperimmune strain $\mathrm{BC}-3^{\mathrm{T}}$ antiserum was prepared as described previously (87). Disk growth inhibition tests $(21,95)$ were performed with spiroplasmas grown in M1D medium. The antigens grown in broth were usually diluted to a concentration of about $10^{5} \mathrm{CCU} / \mathrm{ml}$. The techniques used for the deformation test, the metabolism inhibition test and the enzyme-linked immunosorbent assay have been described previously $(73,102,105)$. Metabolism inhibition test antigens were prepared from cultures grown for $24 \mathrm{~h}$ at $30^{\circ} \mathrm{C}$ in SP-4 broth, and most of the test procedures were performed in SP-4 broth. The metabolism inhibition antigen for spiroplasma strain E275 was grown in M1A broth, and the test procedures were performed in this medium.

PAGE. The techniques used to determine patterns of cell proteins in one- and two-dimensional PAGE gels have been described previously (58).

Genomic analysis. The techniques used to extract DNA and to determine (by buoyant density, melting point, and 
TABLE 2. Growth of strain BC- $3^{\mathrm{T}}$ at different temperatures"

\begin{tabular}{crrrr}
\hline \multirow{2}{*}{ Temp $\left({ }^{\circ} \mathrm{C}\right)$} & \multicolumn{4}{c}{ CCU titer on day: ${ }^{b}$} \\
\cline { 2 - 5 } & 1 & 2 & 4 & 7 \\
\hline 20 & 7 & 7 & 8 & 8 \\
25 & 8 & 8 & 10 & 9 \\
30 & 8 & 8 & 10 & 9 \\
32 & 9 & 10 & 9 & 10 \\
35 & 9 & 9 & 9 & 6 \\
37 & 9 & 9 & 9 & 6 \\
\hline
\end{tabular}

${ }^{a}$ The initial inoculum level (zero time) was about $10^{6} \mathrm{CCU}$.

${ }^{b} \mathrm{CCU}$ titers, given as $\log _{10}$ units, are defined as the reciprocals of the endpoint titers in 10-fold dilution series in SP-4 broth medium.

high-pressure liquid chromatography) the guanine-pluscytosine $(\mathrm{G}+\mathrm{C})$ contents of the DNAs of subgroup I-2 spiroplasmas have been described previously $(6,10,11,47)$. The techniques used for restriction enzyme analysis of DNA have also been described previously (72).

\section{RESULTS}

Morphological and cultural properties. Primary isolation of strain $\mathrm{BC}-3^{\mathrm{T}}$ was accomplished by transferring honeybee hemolymph to SM-1 medium and maintaining the culture at $30^{\circ} \mathrm{C}$. Subcultures were readily established in this medium; the cultures grew rapidly, produced turbidity, and acidified the medium within $24 \mathrm{~h}$. Similar rapid growth was apparent when the organisms were subcultured in most other spiroplasma broth media (M1A, M1D, SP-4, BSR, and other media) or in conventional mycoplasma media (media containing $20 \%$ horse serum broth or $1 \%$ serum fraction). The presence of penicillin $(500 \mathrm{U} / \mathrm{ml})$ had no influence on growth rates or yields. Strain BC- $3^{\mathrm{T}}$ grew rapidly in M1D medium. When a $10 \%$ inoculum was used, this organism grew to a titer of about $10^{10} \mathrm{CCU} / \mathrm{ml}$ in $24 \mathrm{~h}$ at $30^{\circ} \mathrm{C}$. The terminal $\mathrm{pH}$ was about 4.7. The morphological features of strain $B C-3^{\mathrm{T}}$ and related strains were essentially the same as those of the $\mathrm{R} 8 \mathrm{~A} 2^{\mathrm{T}}$ strain of $S$. citri $(22)$. Although strain $\mathrm{BC}-3^{\mathrm{T}}$ grew at each of the temperatures tested (Table 2), growth was more rapid at 32 to $37^{\circ} \mathrm{C}$. Titers of $10^{10} \mathrm{CCU} / \mathrm{ml}$ were achieved at 25 to $32^{\circ} \mathrm{C}$. Growth at $20^{\circ} \mathrm{C}$ was measurably slower, and the peak titer was only $10^{8} \mathrm{CCU} / \mathrm{ml}$. Cultures examined by dark-field microscopy contained numerous helical cells which frequently flexed and twitched and occasionally appeared to exhibit rotatory motility. In stationary growth (cultures held at $30^{\circ} \mathrm{C}$ for more than $48 \mathrm{~h}$ ), the organisms became deformed, but some evidence of helicity persisted for many days. Cells grown in SM-1 medium were examined by electron microscopy. When negative staining or sectioning procedures were used, no cell wall material or periplasmic fibrils were observed. Thin sections revealed only a typical single membrane surrounding each cell (Fig. 1). As with other spiroplasmas $(40,103)$, one end of the helix appeared to be more pointed than the other.

Strain $\mathrm{BC}-3^{\mathrm{T}}$ and other subgroup I-2 spiroplasmas formed diffuse colonies on solid medium containing $0.8 \%$ Noble agar. Classic "fried-egg" colonies, such as those observed with most nonhelical mollicutes, were not formed. Colonies on "soft" agar appeared only after 3 to 4 days of incubation at $30^{\circ} \mathrm{C}$ and when plates were maintained in an anaerobic environment (GasPak; BBL). When 2.25\% Noble agar (hard agar) was added to media (i.e., $1 \%$ serum fraction broth or SP-4 broth), the colonies were smaller and granular but frequently showed some fried-egg colony morphology (Fig. 2). Although most colonies on these media exhibited a dense core, the amount of peripheral growth varied considerably, and some satellite growth was observed around the central zone. This satellite growth suggests that some spiroplasmas had migrated through the agar from the primary site of growth. Colonies on hard serum fraction agar appeared after incubation for 3 or more days and under the same gaseous environments as the diffuse colonies on soft agar.

Reversion studies. Cultures of strain $B C-3^{T}$ that were maintained in antibiotic-free broth medium for five passages did not revert to bacterial forms. Cultures examined by dark-field microscopy contained typical helical organisms, with no evidence of walled forms. Also, colonies failed to develop when cultures were plated on $5 \%$ sheep blood agar.

Filtration studies. An $18 \mathrm{~h}$ broth culture of strain BC-3 ${ }^{\mathrm{T}}$ contained $10^{10} \mathrm{CCU} / \mathrm{ml}$ before filtration through a series of graded membrane filters. The number of $\mathrm{CCU}$ per milliliter after filtration through membrane filters having average pore diameters of 450,300 , and $220 \mathrm{~nm}$ were $10^{10}, 10^{8}$, and $10^{7}$, respectively. The organisms did not pass through membrane filters with average pore diameters of $100 \mathrm{~nm}$.

Biochemical and biological properties. Strain $B C-3^{T}$ fermented glucose and hydrolyzed arginine, whether or not glucose was present in the medium. As with $S$. citri (79), when both substrates were present, the medium first became acid, but eventually became basic as arginine was catabolized. Fifteen strains (BC- $3^{\mathrm{T}}, \mathrm{BC}-4, \mathrm{BC}-5, \mathrm{G}-1, \mathrm{BU}-1, \mathrm{BU}-2$, KC-3, R667, R670, BP-1, AA-1, AA-2, OC-3, BI-2, and AS-3) fermented glucose and catabolized arginine. One strain (BF-1) was positive only for arginine catabolism, and two strains (AS 576 and BW) were positive only for glucose fermentation. Strain $\mathrm{BC}-3^{\mathrm{T}}$ did not hydrolyze urea. Other properties of strain $\mathrm{BC}-3^{\mathrm{T}}$ are summarized below.

Sterol requirement. Significant growth of strain $B C-3^{T}$ was not observed in the serum-free base medium or when supplements of albumin, palmitic acid, and Tween 80 were

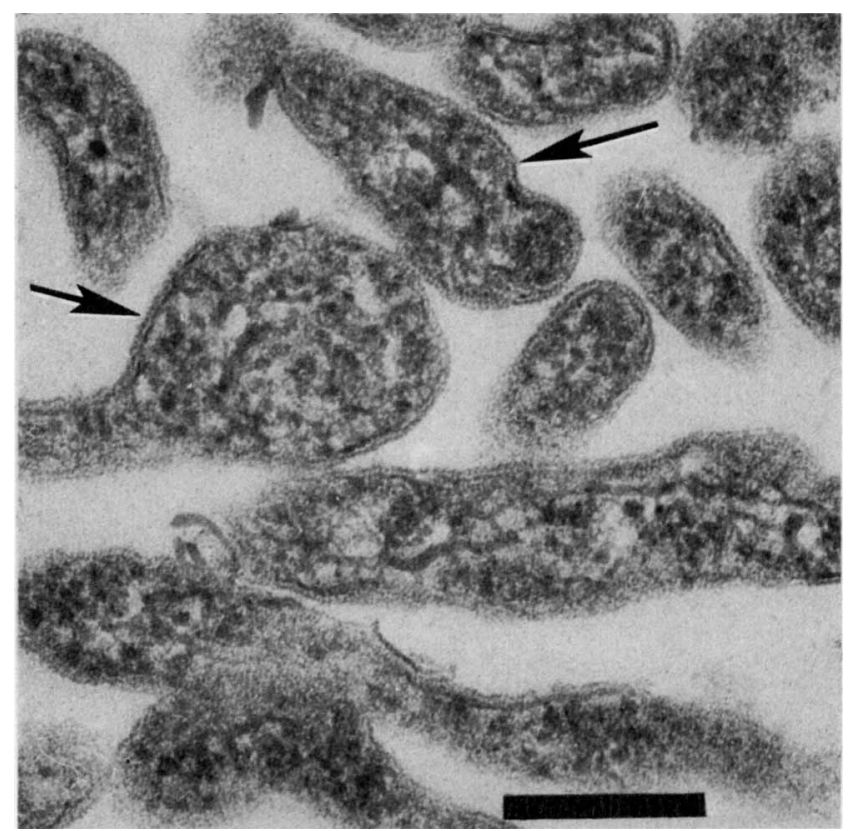

FIG. 1. Electron micrograph of strain $\mathrm{BC}-3^{\mathrm{T}}$. Thin-section preparation of a cell pellet obtained from a 48 -h broth culture stained with uranyl acetate. Note the unit membrane (arrows) on the cells. $\mathrm{Bar}=100 \mathrm{~nm}$. 


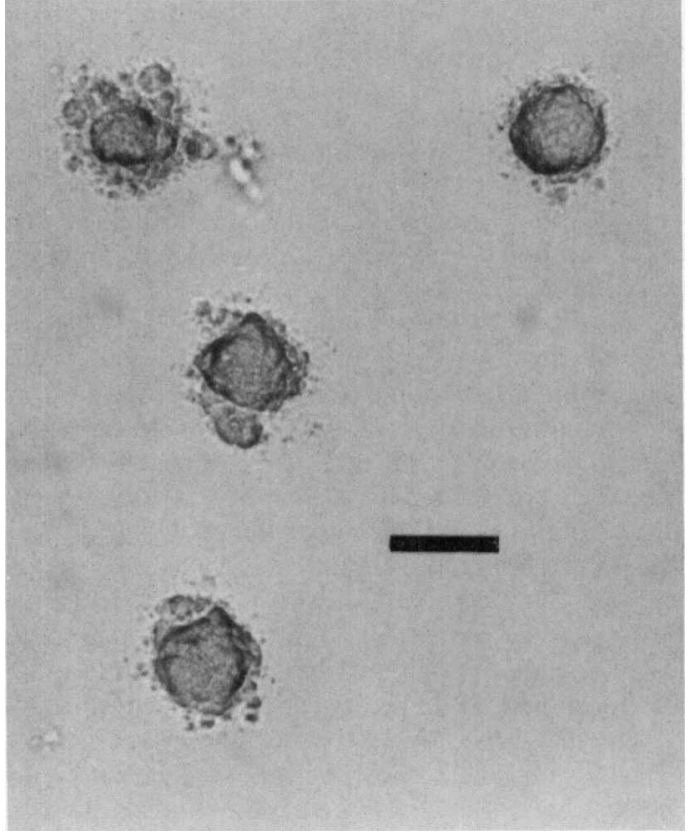

FIG. 2. Colonies of strain BC- $3^{\mathrm{T}}$ on SP-4 hard agar after 10 days of incubation at $30^{\circ} \mathrm{C}$ in an anaerobic environment (GasPak). Bar $=$ $100 \mu \mathrm{m}$.

added (Table 3). However, the addition of 5 to $20 \mu \mathrm{g}$ of cholesterol per ml to the base medium containing fatty acid supplements resulted in significant growth stimulation of strain $\mathrm{BC}-3^{\mathrm{T}}$.

Serological tests. Sera prepared against strain $\mathrm{BC}-3^{\mathrm{T}}$ gave zones of homologous growth inhibition with diameters that ranged from 12 to $14 \mathrm{~mm}$ (Table 4). Growth inhibition was observed in reciprocal tests of strain $\mathrm{BC}-3^{\mathrm{T}}$ with other strains of the $S$. citri complex. Antiserum prepared against the Drosophila sex ratio organism (group II) or antisera directed against other representatives of serogroups III through XI also failed to inhibit the growth of strain BC- $3^{\mathrm{T}}$. Reciprocal deformation and metabolism inhibition tests (Tables 5 and 6 ) confirmed the distinctiveness of strain $\mathrm{BC}-3^{\mathrm{T}}$ from all existing groups, subgroups, and species. The results of the enzyme-linked immunosorbent assay (Table 7) also confirmed these serological patterns. Thus, serological data demonstrated that strain $\mathrm{BC}-3^{\mathrm{T}}$ represents a serological subgroup that is distinguishable from other subgroups of the

TABLE 3. Sterol requirement test for strain $B C-3^{T}$

\begin{tabular}{cc}
\hline $\begin{array}{c}\text { Concn of cholesterol in } \\
\text { medium }(\mu \mathrm{g} / \mathrm{ml})\end{array}$ & $\begin{array}{c}\text { Amt of cell protein } \\
(\mathrm{mg})^{a}\end{array}$ \\
\hline $0^{b}$ & $<0.02$ \\
$0^{c}$ & $<0.02$ \\
$0^{d}$ & $<0.02$ \\
1.0 & 0.45 \\
5.0 & 2.16 \\
10.0 & 2.80 \\
20.0 & 3.06 \\
Control $^{e}$ & 2.97 \\
\hline
\end{tabular}

a Amount of protein in a cell pellet obtained from $100 \mathrm{ml}$ of growth medium.

${ }^{b}$ Serum-free medium.

c Serum-free medium supplemented with $0.5 \%$ albumin and $10 \mu \mathrm{g}$ of palmitic acid per $\mathrm{ml}$.

${ }^{d}$ Serum-free medium supplemented with $0.5 \%$ albumin, $10 \mu \mathrm{g}$ of palmitic acid per $\mathrm{ml}$, and $0.01 \%$ Tween 80 .

${ }^{e}$ Medium containing $1 \%$ bovine serum fraction.
TABLE 4. Growth inhibition tests with strain BC-3

\begin{tabular}{|c|c|c|c|c|}
\hline \multirow[b]{2}{*}{ Serogroup } & \multirow[b]{2}{*}{ Strain } & \multicolumn{3}{|c|}{ Diam of inhibition zone $(\mathrm{mm})$} \\
\hline & & $\begin{array}{l}\text { Strain } \mathrm{BC}-3^{\mathrm{T}} \\
\text { antigen vs } \\
\text { heterologous } \\
\text { antiserum }\end{array}$ & $\begin{array}{c}\text { Strain } \mathrm{BC}-3^{\mathrm{T}} \\
\text { antiserum vs } \\
\text { heterologous } \\
\text { antigen }\end{array}$ & $\begin{array}{l}\text { Homologous } \\
\text { reaction }\end{array}$ \\
\hline $\mathrm{I}-1$ & $\begin{array}{l}\text { S. citri } \\
\text { R8A2 }^{\mathrm{T}}\end{array}$ & $10^{a}$ & 12 & 16 \\
\hline $\mathrm{I}-2$ & $\mathrm{BC}-3^{\mathrm{T}}$ & & & 12 \\
\hline $\mathrm{I}-3$ & E275 & 4 & 12 & 18 \\
\hline $\mathrm{I}-4$ & $277 \mathrm{~F}$ & $\mathrm{~N}^{b}$ & 2 & 14 \\
\hline $\mathrm{I}-5$ & LB-12 & 2 & 5 & 18 \\
\hline $\mathrm{I}-6$ & M55 & 1 & 3 & 13 \\
\hline $\mathrm{I}-7$ & N525 & $\mathrm{N}$ & 1 & 11 \\
\hline $\mathrm{I}-8$ & P40 & 2 & 12 & 17 \\
\hline II & WSRO & $\mathbf{N}$ & $\mathrm{ND}^{c}$ & ND \\
\hline III & $\begin{array}{l}\text { S. floricola } \\
\text { OBMG }\end{array}$ & $\mathrm{N}$ & $\mathrm{N}$ & 6 \\
\hline IV & $\begin{array}{l}\text { S. apis } \\
\mathrm{B}^{3} 1^{\mathrm{T}}\end{array}$ & $\mathrm{N}$ & $\mathrm{N}$ & 5 \\
\hline V & $\begin{array}{l}\text { S. mirum } \\
\text { SMCA }^{\mathrm{T}}\end{array}$ & 1 & $\mathrm{~N}$ & 13 \\
\hline VI & Y32 & $\mathrm{N}$ & $\mathrm{N}$ & 16 \\
\hline VII & MQ-1 & $\mathrm{N}$ & $\mathrm{N}$ & 6 \\
\hline VIII & EA-1 & $\mathrm{N}$ & $\mathbf{N}$ & 10 \\
\hline IX & CN-5 & $\mathrm{N}$ & $\mathrm{N}$ & 8 \\
\hline
\end{tabular}

" Diameter of inhibition zone around disk saturated with antiserum.

${ }^{b} \mathrm{~N}$, No zone of inhibition.

${ }^{c}$ ND. Not done.

S. citri complex; from $S$. floricola, S. apis, and S. mirum; and from all other designated spiroplasma serogroups.

The homogeneity of the subgroup I-2 organisms was assessed (Table 8 ) by testing 17 strains against antisera to

TABLE 5. Deformation tests with strain BC-3 ${ }^{\mathrm{T}}$

\begin{tabular}{|c|c|c|c|c|}
\hline \multirow[b]{2}{*}{ Serogroup } & \multirow[b]{2}{*}{ Strain } & \multicolumn{3}{|c|}{ Titer } \\
\hline & & $\begin{array}{l}\text { Strain } \\
\text { BC- } 3^{\mathrm{T}} \text { anti- } \\
\text { gen vs het- } \\
\text { erologous } \\
\text { antiserum }\end{array}$ & $\begin{array}{c}\text { Strain BC-3 } \\
\text { antiserum vs } \\
\text { heterologous } \\
\text { antigen }\end{array}$ & $\begin{array}{l}\text { Homologous } \\
\text { reaction }\end{array}$ \\
\hline$I-1$ & $\begin{array}{l}\text { S. citri } \\
\text { R8A2 }^{\mathrm{T}}\end{array}$ & $2,560^{a}$ & 320 & 2,560 \\
\hline I-2 & $B C-3^{\mathrm{T}}$ & & & 10,240 \\
\hline I-3 & E275 & 160 & 640 & 20,240 \\
\hline $\mathrm{I}-4$ & $277 \mathrm{~F}$ & 40 & 40 & 5,120 \\
\hline $1-5$ & LB-12 & 320 & 40 & 5,120 \\
\hline I-6 & M55 & 160 & $\mathrm{~N}$ & 1,280 \\
\hline $\mathrm{I}-7$ & N525 & 160 & 40 & 10,240 \\
\hline I-8 & P40 & 320 & 160 & 10,240 \\
\hline II & WSRO & $\mathrm{N}^{b}$ & $\mathrm{~N}$ & 4,000 \\
\hline III & $\begin{array}{l}\text { S. floricola } \\
\text { OBMG }\end{array}$ & $N$ & $\mathrm{~N}$ & 10,240 \\
\hline IV & $\begin{array}{l}\text { S. apis } \\
{\mathrm{B} 31^{\mathrm{T}}}^{\mathrm{T}}\end{array}$ & $\mathrm{N}$ & $\mathrm{N}$ & 1,280 \\
\hline V & $\begin{array}{l}\text { S. mirum } \\
\mathrm{SMCA}^{\mathrm{T}}\end{array}$ & $\mathrm{N}$ & $\mathrm{N}$ & 5,120 \\
\hline VI & Y32 & $\mathrm{N}$ & $\mathrm{N}$ & 2,560 \\
\hline VII & MQ-1 & $\mathrm{N}$ & $\mathrm{N}$ & 1,280 \\
\hline VIII & EA-1 & $\mathrm{N}$ & $\mathrm{N}$ & 1,280 \\
\hline IX & $\mathrm{CN}-5$ & $\mathrm{~N}$ & $\mathrm{~N}$ & 1,280 \\
\hline
\end{tabular}

"Reciprocal of the highest antiserum dilution which deformed at least $50 \%$ of the helices.

${ }^{b} \mathrm{~N}$, Deformation titer less than 20 . 
TABLE 6. Metabolism inhibition tests with strain $\mathrm{BC}-3^{T}$

\begin{tabular}{|c|c|c|c|c|}
\hline \multirow[b]{2}{*}{ Serogroup } & \multirow[b]{2}{*}{ Strain } & \multicolumn{3}{|c|}{ Titer } \\
\hline & & $\begin{array}{l}\text { Strain } \mathrm{BC}-3^{\mathrm{T}} \\
\text { antigen vs } \\
\text { heterologous } \\
\text { antiserum }\end{array}$ & $\begin{array}{l}\text { Strain } \mathrm{BC}-3^{\mathrm{T}} \\
\text { antiserum vs } \\
\text { heterologous } \\
\text { antigen }\end{array}$ & $\begin{array}{l}\text { Homolo- } \\
\text { gous reac- } \\
\text { tion }\end{array}$ \\
\hline $\mathrm{I}-1$ & $\begin{array}{l}\text { S. citri } \\
\text { R8A2 }^{\mathrm{T}}\end{array}$ & $486^{a}$ & 1,458 & $>117,000$ \\
\hline $\mathrm{I}-2$ & $\mathrm{BC}-3^{\mathrm{T}}$ & & & 39,000 \\
\hline $1-3$ & E275 & 486 & 54 & 39,000 \\
\hline $\mathrm{I}-4$ & $277 \mathrm{~F}$ & $\mathrm{~N}^{b}$ & $\mathbf{N}$ & 39,000 \\
\hline $\mathrm{I}-5$ & LB-12 & $\mathrm{N}$ & 1,458 & $>117,000$ \\
\hline$I-6$ & M55 & $\mathrm{N}$ & $\mathrm{N}$ & 13,000 \\
\hline $1-7$ & N525 & $\mathrm{N}$ & 162 & 39,000 \\
\hline $\mathrm{I}-8$ & P40 & 486 & 1,458 & $>117,000$ \\
\hline II & WSRO & 54 & $\mathrm{ND}^{c}$ & ND \\
\hline III & $\begin{array}{l}\text { S. floricola } \\
\text { OBMG }\end{array}$ & $\mathrm{N}$ & $\mathbf{N}$ & 13,000 \\
\hline IV & $\begin{array}{l}\text { S. apis } \\
{\text { B } 31^{\mathrm{T}}}^{\mathrm{T}}\end{array}$ & $\mathbf{N}$ & $\mathrm{N}$ & 4,324 \\
\hline $\mathrm{V}$ & $\begin{array}{l}\text { S. mirum } \\
\mathrm{SMCA}^{\mathrm{T}}\end{array}$ & $\mathrm{N}$ & $\mathbf{N}$ & 13,000 \\
\hline VI & Y32 & $\mathrm{N}$ & $\mathrm{N}$ & 4,324 \\
\hline VII & MQ-1 & $\mathrm{N}$ & $\mathrm{N}$ & 39,000 \\
\hline VIII & EA-1 & $\mathrm{N}$ & $\mathrm{N}$ & 13,000 \\
\hline IX & $\mathrm{CN}-5$ & $\mathrm{~N}$ & $\mathrm{~N}$ & 4,374 \\
\hline
\end{tabular}

${ }^{a}$ Reciprocal of the highest antiserum dilution which inhibited metabolism (glucose fermentation).

${ }^{b} \mathrm{~N}$, Titer less than 18

${ }^{c} \mathrm{ND}$, Not done.

strain R8A2 ${ }^{\mathrm{T}}$ (subgroup I-1), strain $\mathrm{BC}-3^{\mathrm{T}}$ (subgroup I-2), and strain E275 (subgroup I-3). Also, 10 subgroup I-1 strains and 9 subgroup I-3 strains were tested. All of the subgroup I-2 strains had titers against homologous antiserum of about 10,240 but had much lower titers in all combinations with sera derived from members of other subgroups. The levels of the heterologous reactions within subgroup strains varied no more than fourfold. Also, strain $\mathrm{BC}-3^{\mathrm{T}}$ and all of the subgroup I-2 strains examined had high titers against antiserum

TABLE 7. Serological relationships, as determined by the enzyme-linked immunosorbent assay

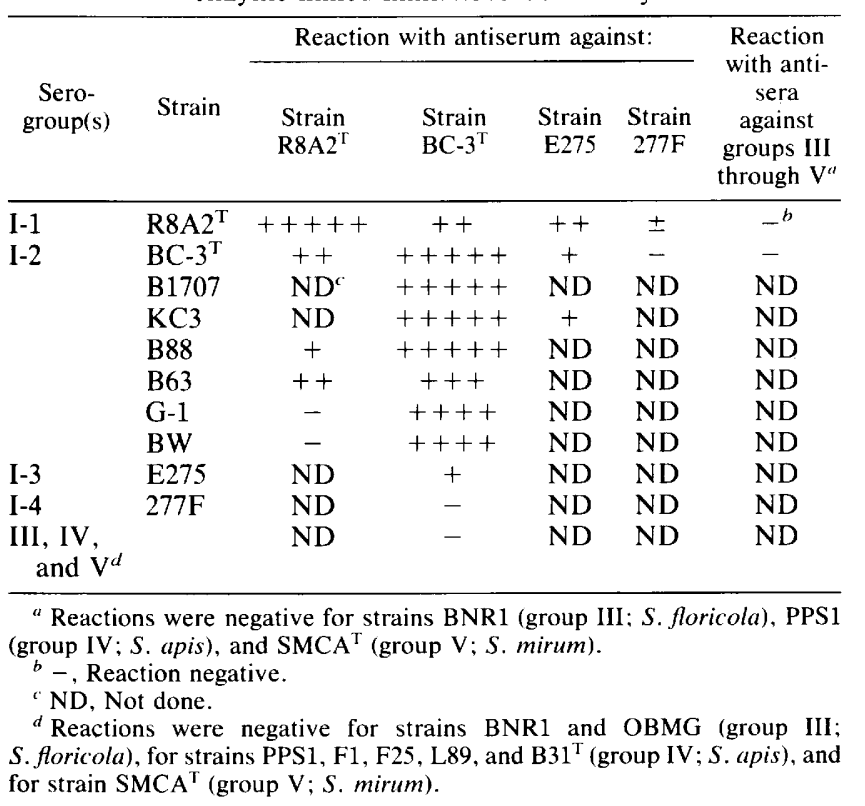

directed against the homologous membrane protein from strain B88. Thus, the 17 strains examined, although they had been isolated from a variety of insect and flower sources, make up a homogeneous cluster that can be readily and rapidly identified by using antiserum directed against wholecell preparations of strain $\mathrm{BC}-3^{\mathrm{T}}$ or specific antiserum to the subgroup I-2 membrane protein.

PAGE. Patterns obtained from one-dimensional (Fig. 3) and two-dimensional (Fig. 4) PAGE of cell proteins confirmed the patterns of partial relationship with other members of the group I complex, as shown by sharing of a number of comigrating proteins. Also, the demonstration that only a limited number of proteins comigrated with proteins of members of groups II through XI confirmed serological and molecular genetic evidence that these

TABLE 8. Results of reciprocal deformation tests between subgroup I-1, I-2, and I-3 isolates and antiserum against the major membrane protein of strain B88 and strain B88 membranes

\begin{tabular}{|c|c|c|c|c|c|}
\hline \multirow[b]{2}{*}{ Strain } & \multicolumn{5}{|c|}{ Titer with antiserum against: } \\
\hline & $\begin{array}{l}\text { S. citri } \\
\text { R8A2 }^{\mathrm{T}}\end{array}$ & $\begin{array}{l}\text { Strain } \\
\mathrm{BC}-3^{\mathrm{T}}\end{array}$ & $\begin{array}{l}\text { Strain } \\
\text { E275 }\end{array}$ & $\begin{array}{c}\text { Strain } \\
\text { B88 } \\
\text { protein }\end{array}$ & $\begin{array}{c}\text { Strain B88 } \\
\text { mem- } \\
\text { branes }\end{array}$ \\
\hline \multicolumn{6}{|l|}{ Subgroup I-2 } \\
\hline $\mathrm{BC}-3^{\mathrm{T}}$ & $640^{a}$ & 5,120 & 160 & 1,280 & 2,560 \\
\hline AS 576 & 80 & 2,560 & 20 & 640 & 1,280 \\
\hline $\mathrm{KC}-3$ & 80 & 1,280 & 160 & 1,280 & 1,280 \\
\hline BU-2 & 640 & 2,560 & 160 & 1,280 & 1,280 \\
\hline BC -6 & 80 & 5,120 & 80 & $\mathrm{ND}^{b}$ & ND \\
\hline BU-1 & 80 & 2,560 & 160 & 640 & 1,280 \\
\hline $\mathrm{R} 667$ & 640 & 5,120 & 160 & 640 & 320 \\
\hline R670 & 640 & 2,560 & 160 & 1,280 & 640 \\
\hline G-1 & 1,280 & 2,560 & 40 & 2,560 & 2,560 \\
\hline AA-1 & 320 & 2,560 & 160 & ND & ND \\
\hline AA-2 & ND & 2,560 & 80 & 640 & 1,280 \\
\hline $\mathrm{BI}-2$ & 80 & 5,120 & 80 & ND & ND \\
\hline AS-3 & 320 & 2,560 & 160 & 1,280 & 5,120 \\
\hline BC-5 & 320 & 2,560 & 40 & 1,280 & 5,120 \\
\hline BF-1 & 160 & 2,560 & 80 & 640 & 1,280 \\
\hline BC-4 & 80 & 2,560 & 80 & 1,280 & 2,560 \\
\hline BP-1 & 80 & 2,560 & 20 & 1,280 & 2,560 \\
\hline \multicolumn{6}{|c|}{$\begin{array}{l}\text { Spiroplasma citri } \\
\text { (subgroup I-1) }\end{array}$} \\
\hline $\begin{array}{l}\mathrm{R} 8 \mathrm{~A} 2^{\mathrm{T}} \\
\quad\left(=\mathrm{Maroc}^{\mathrm{T}}\right)\end{array}$ & 2,560 & 20 & 20 & $-c$ & 20 \\
\hline $\mathrm{C} 189$ & 5,120 & 80 & 20 & 40 & 40 \\
\hline Israel & 2,560 & 40 & 20 & 40 & 20 \\
\hline ASP-1 & 1,280 & $\mathrm{~N}$ & 20 & 20 & 20 \\
\hline Iran & 5,120 & 40 & 20 & 40 & 40 \\
\hline $\mathrm{E} 2245$ & 2,560 & 40 & 40 & 80 & 40 \\
\hline $\mathrm{SCC}$ & 5,120 & 20 & 20 & 80 & 40 \\
\hline Aceratagallia & 2,560 & 20 & 20 & 40 & 20 \\
\hline CB-1 & 5,120 & 20 & 20 & 40 & 40 \\
\hline B106 & 5,120 & 40 & 20 & 80 & 20 \\
\hline
\end{tabular}

Corn stunt spiroplasma (subgroup [-3)

$\begin{array}{lrrr}\text { E275 } & 80 & 320 & 40,960 \\ \text { I-747 } & 80 & 320 & 40,960 \\ \text { Miss E } & 80 & 640 & 20,480 \\ \text { B655 } & 80 & 320 & 40,960 \\ \text { B647 } & 40 & 80 & 20,480 \\ \text { B652 } & 40 & 160 & 10,240 \\ \text { CRL } & 20 & \text { ND } & 20,480 \\ \text { CSEE1 } & 40 & \text { ND } & 20,480 \\ \text { CSEE2 } & 40 & 80 & 20,480\end{array}$

a Reciprocal of the highest antiserum dilution which deformed at least $50 \%$ of the helices.

${ }^{b} \mathrm{ND}$, Not done.

$c$-, Reaction negative. 
serogroups of subgroup I-2 are distinct and represent putative species.

Genomic analysis. The $\mathrm{G}+\mathrm{C}$ content of the DNA of strain $\mathrm{BC}-3^{\mathrm{T}}$ was determined from its melting temperature (assayed spectrophotometrically in six independent analyses), from its buoyant density (obtained by equilibrium centrifugation in $\mathrm{CsCl}_{2}$ in six independent analyses), and by high-pressure liquid chromatography (four independent analyses). The $\mathrm{G}+\mathrm{C}$ content was about 27 to $28 \mathrm{~mol} \%$ as determined by the buoyant density method, $28.8 \mathrm{~mol} \%$ as determined by high-pressure liquid chromatography, and about $26 \mathrm{~mol} \%$ as determined by the melting temperature method (Table 9). The values obtained for other members of the strain assemblage (Table 9) were close to the values obtained for strain $\mathrm{BC}-3^{\mathrm{T}}$. These values are characteristic of group I spiroplasmas (5). The patterns obtained after EcoRI digestion of DNAs (72) extracted from strains $\mathrm{BC}-3^{\mathrm{T}}, \mathrm{B} 88$, and B1707 were similar (Fig. 5).

\section{DISCUSSION}

Strain $\mathrm{BC}-3^{\mathrm{T}}$ has been used as a model in many studies of basic spiroplasma biology, and a considerable amount of information regarding this strain has therefore been reported. A second strain from Maryland honeybees, strain AS 576, has also been used in certain studies. Strain BC- $3^{\mathrm{T}}$ has been used as the representative strain of subgroup $1-2$ in most serological studies. Serological justification for the assignment of a binomial name to subgroup I-2 spiroplasmas has been obtained from growth inhibition (95), deformation $(102,105)$, and metabolism inhibition $(93,102)$ tests, as well as by crossed-immunoelectrophoresis $(2,3)$, enzyme-linked immunosorbent assay $(73,85$; C. Saillard, Thèse Doctorat, Université de Bordeaux II, Bordeaux, France, 1981), and immuno-double-diffusion (23) procedures. All of these tests have confirmed that strain $\mathrm{BC}-3^{\mathrm{T}}$ differs significantly from other named species $(30,60,71,89)$ and from other serogroups in the scheme proposed by Junca et al. (47) and subsequently revised $(93,94)$. The results of these studies also confirm that there is a rather complex pattern of interrelatedness among the eight subgroups of the $S$. citri complex.

The discovery of serological interrelatedness among group I strains provoked more refined analyses, such as those involving genomic characteristics of the organisms. Studies of the DNA-DNA hybridization reactions of group I strains revealed that strain $\mathrm{BC}-3^{\mathrm{T}}$ showed about 65 to $70 \%$ relatedness when it was tested against $S$. citri probes and only $50 \%$ relatedness when it was tested against strain CSS $(5,47)$; reactions with strains of other group I subgroups were of lower magnitude. These studies established that the taxonomic distance between strain $\mathrm{BC}-3^{\mathrm{T}}$ and the type species of the genus (and the group I species complex) was in a "gray area," in which other criteria would be required to make a taxonomic decision.

Studies of the spiroplasma genome were supplemented by comparisons of cell proteins by one-dimensional PAGE by us and by other workers (24) and by more extensive and refined studies in which two-dimensional analyses were performed $(5,61-63)$. The results of these studies closely paralleled the results obtained in studies of the genome. Although strain $B C-3^{T}$ possessed a number of unique proteins, it shared a significant number of comigrating proteins $(45 \%)$, as well as a significant number of homologous proteins (31\%), with $S$. citri $\mathrm{R} 8 \mathrm{~A} 2^{\mathrm{T}}$ (5). The one-dimensional and two-dimensional PAGE protein patterns of group I-2 strains are very similar but they are distinct from the

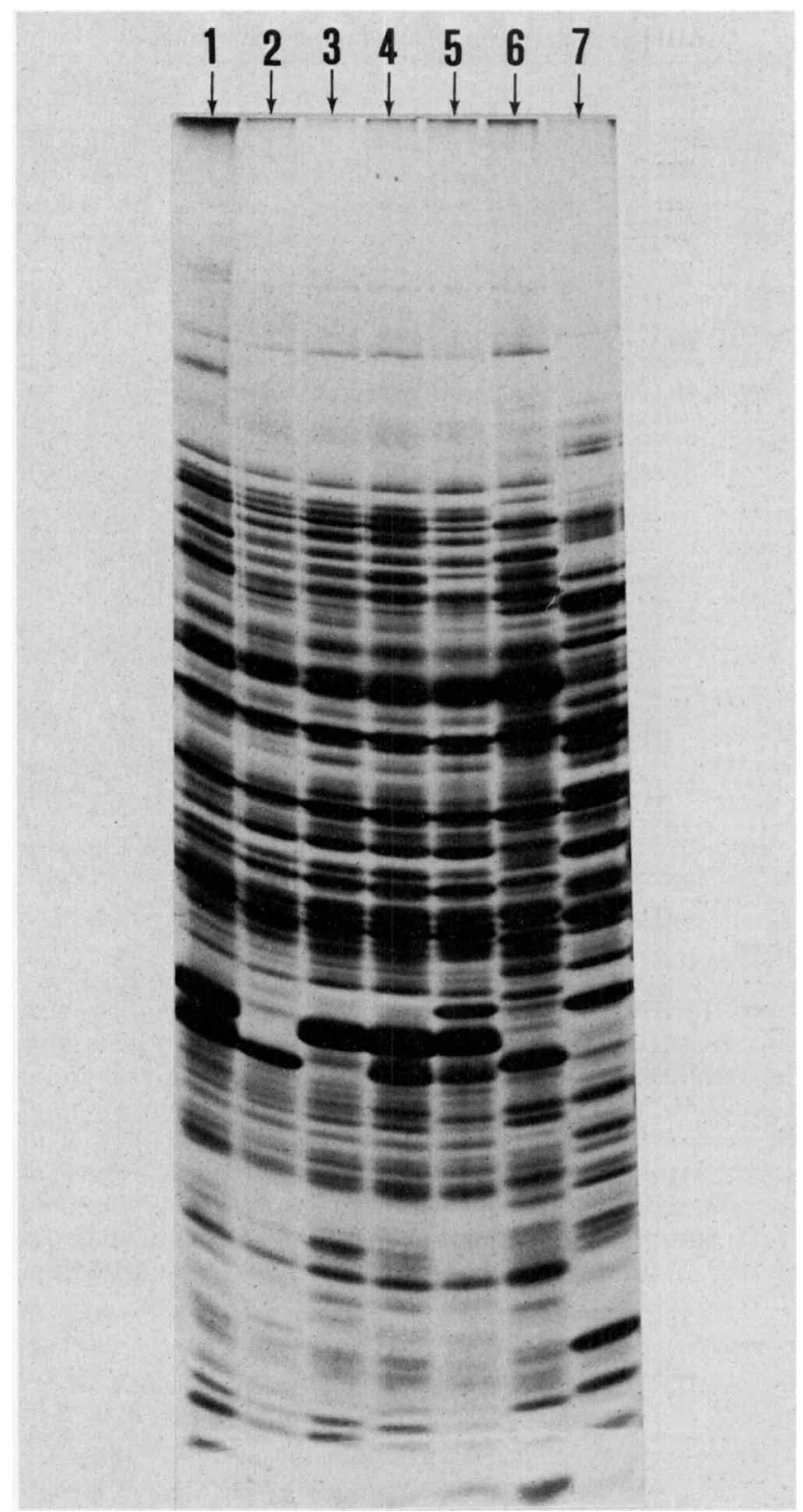

FIG. 3. One-dimensional PAGE protein profiles of subgroup I-2 spiroplasmas. Track 1 , Strain $\mathrm{BC}-3^{\mathrm{T}}$ (subgroup I-2); track 2 , strain B63 (subgroup I-2); track 3, strain KC-3 (subgroup I-2); track 4, strain AS 576 (subgroup I-2); track 5, strain G-1 (subgroup I-2); track 6, strain R8A2 ${ }^{\mathrm{T}}$ (S. citri) (subgroup I-1); track 7, strain B31 ${ }^{\mathrm{T}}$ (S. apis) (group IV).

patterns of members of other group I subgroups. Of course, the patterns observed with all group I strains are very distinct from the patterns of members of other subgroups (serogroups II through XI).

Development of techniques for purifying the major membrane protein of $S$. citri $(107)$ has led to a more refined understanding of the serological reactions of spiroplasmas. Rabbits hyperimmunized with the major membrane protein from S. citri (spiralin) (107) produce antibodies that are largely specific for subgroup I-1 spiroplasmas (97, 107). When these antibodies were tested by crossed-immunoelectrophoresis $(2,3)$, a relatively insensitive technique, the specificity of the serum appeared to be very high. 


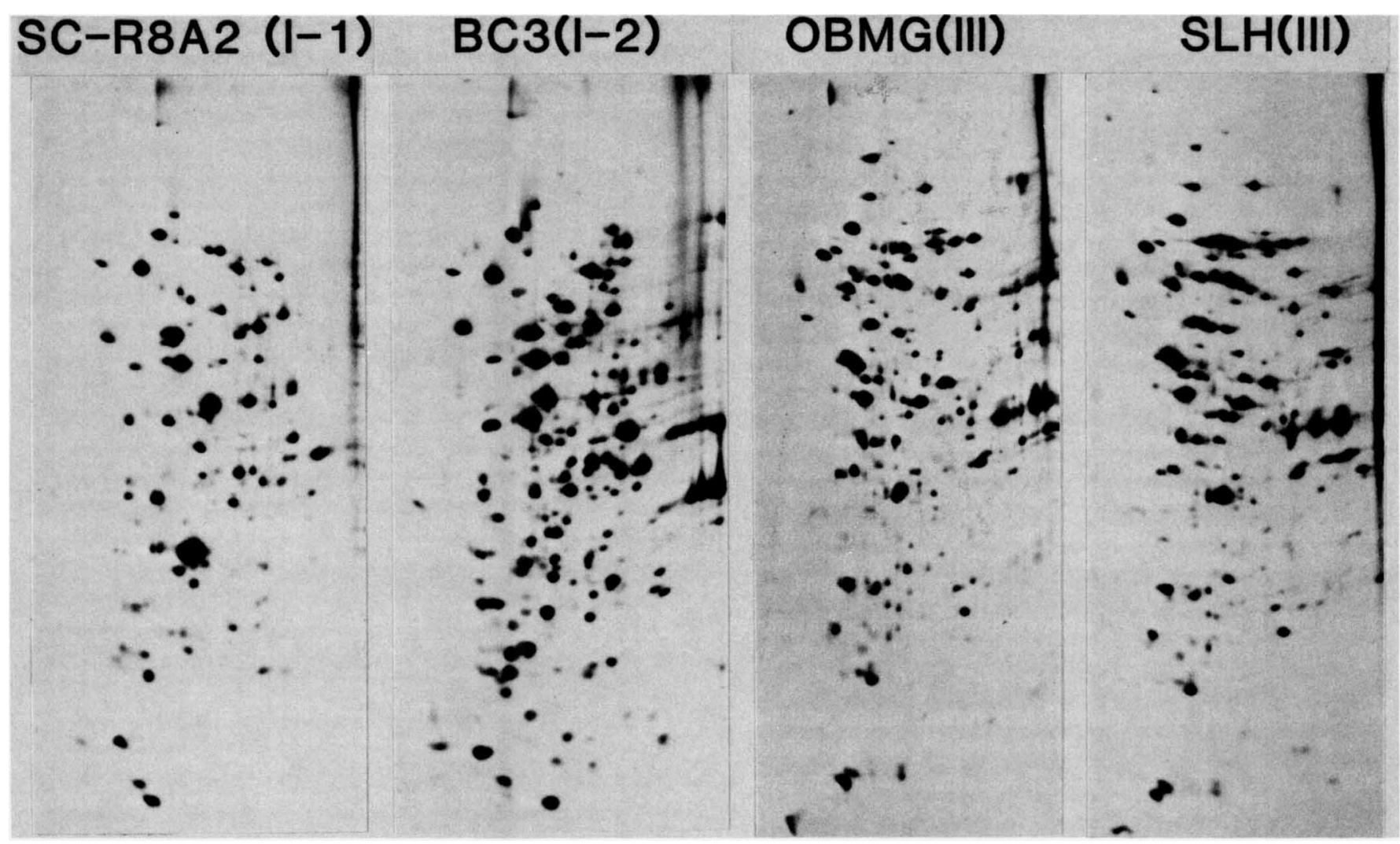

FIG. 4. Two-dimensional PAGE protein profiles of strain $\mathrm{BC}^{-3^{\mathrm{T}}}$ (subgroup $\mathrm{I}-2$ ), $S$. citri $\mathrm{R} 8 \mathrm{~A} 2^{\mathrm{T}}$ (subgroup $\mathrm{I}-1$ ), and $S$. floricola strains OBMG and SLH (group III).

However, when they were examined by tests as sensitive as metabolism inhibition, minor cross-reactions became apparent (97). These cross-reactions were strongest with strain $B C-3^{\mathrm{T}}$. Sera directed against spiralin and the serum directed against the spiralin homolog from strain B88 of subgroup I-2 described above were almost completely specific for their subgroups of origin, and the serological reactions involving antibodies to such membrane proteins account for a signifi- cant fraction of the serological cross-reactivity in growth inhibition, deformation, and metabolism inhibition tests (97).

Subgroup I-2 strains carry at least two types of virus. Group I viruses ( $\mathrm{SpV} 1$ ), which are unenveloped rods that are 230 to 280 by 10 to $15 \mathrm{~nm}$ were found in strains $\mathrm{G}-1, \mathrm{BC}-3^{\mathrm{T}}$, and $\mathrm{KC}-3(52,53)$. These viruses plaqued on strains $\mathrm{BC}-3^{\mathrm{T}}$, AS 576, and G-1, but the infections were nonlytic. Another strain (strain B63) was found to carry a new viral type

TABLE 9. G $+\mathrm{C}$ contents of subgroup $\mathrm{I}-1$ and $\mathrm{I}-2$ spiroplasmas

\begin{tabular}{|c|c|c|c|c|c|c|}
\hline \multirow[b]{2}{*}{ Strain } & \multicolumn{3}{|c|}{$\begin{array}{c}\mathrm{G}+\mathrm{C} \text { contents }(\mathrm{mol} \%) \text { as } \\
\text { determined by: }\end{array}$} & \multicolumn{3}{|c|}{$\begin{array}{l}\text { Mean } \mathrm{G}+\mathrm{C} \text { contents }(\mathrm{mol} \%) \text { as } \\
\text { determined by: }\end{array}$} \\
\hline & Buoyant density & Melting temp & $\begin{array}{l}\text { High-pressure } \\
\quad \text { liquid } \\
\text { chromatography }\end{array}$ & $\begin{array}{l}\text { Buoyant } \\
\text { density }\end{array}$ & $\begin{array}{l}\text { Melting } \\
\text { temp }\end{array}$ & $\begin{array}{l}\text { High-pressure } \\
\text { liquid } \\
\text { chromatography }\end{array}$ \\
\hline S. citri $\mathrm{R} 8 \mathrm{~A} 2^{\mathrm{T}}$ & $\begin{array}{l}25.2,25.8,26.7,25.9 \\
26.5,25.7\end{array}$ & $\begin{array}{l}26.0,26.0,26.0,26.0 \\
26.0,26.0\end{array}$ & & 26.0 & 26.0 & \\
\hline $\mathrm{BC}-3^{\mathrm{T}}$ & $\begin{array}{l}27.8,27.9,27.8,27.7, \\
27.5,27.6\end{array}$ & $\begin{array}{l}26.0,25.6,26.0,26.2 \\
24.3,26.0\end{array}$ & $29.6,27.5,28.5,29.6$ & 27.7 & 25.7 & 28.8 \\
\hline KC-3 & $\begin{array}{l}28.3,27.7,28.3,28.0, \\
27.9,27.9\end{array}$ & $\begin{array}{l}28.0,26.0,26.0,26.6 \\
26.2,25.8\end{array}$ & & 28.0 & 26.4 & \\
\hline B63 & $27.2,27.0,26.9,27.5$ & $26.5,26.0,26.5$ & & 27.2 & 26.3 & \\
\hline B88 & $27.0,27.9$ & $27.0,26.0,26.0,26.0$ & $\begin{array}{l}28.0,26.2,27.7,27.1 \\
28.1,27.4,26.0 \\
27.9\end{array}$ & 27.4 & 26.2 & 27.3 \\
\hline B1707 & $27.8,28.3$ & $\mathrm{ND}^{a}$ & & 28.0 & & \\
\hline AS 576 & $27.6,27.6,27.5$ & ND & & 27.6 & & \\
\hline G-1 & $28.0,27.7,27.5$ & ND & & 27.7 & & \\
\hline $\mathrm{BW}$ & $27.2,26.5,26.5,27.3$ & $26.0,25.5$ & & 26.9 & 25.8 & \\
\hline
\end{tabular}

${ }^{a} \mathrm{ND}$, Not determined. 


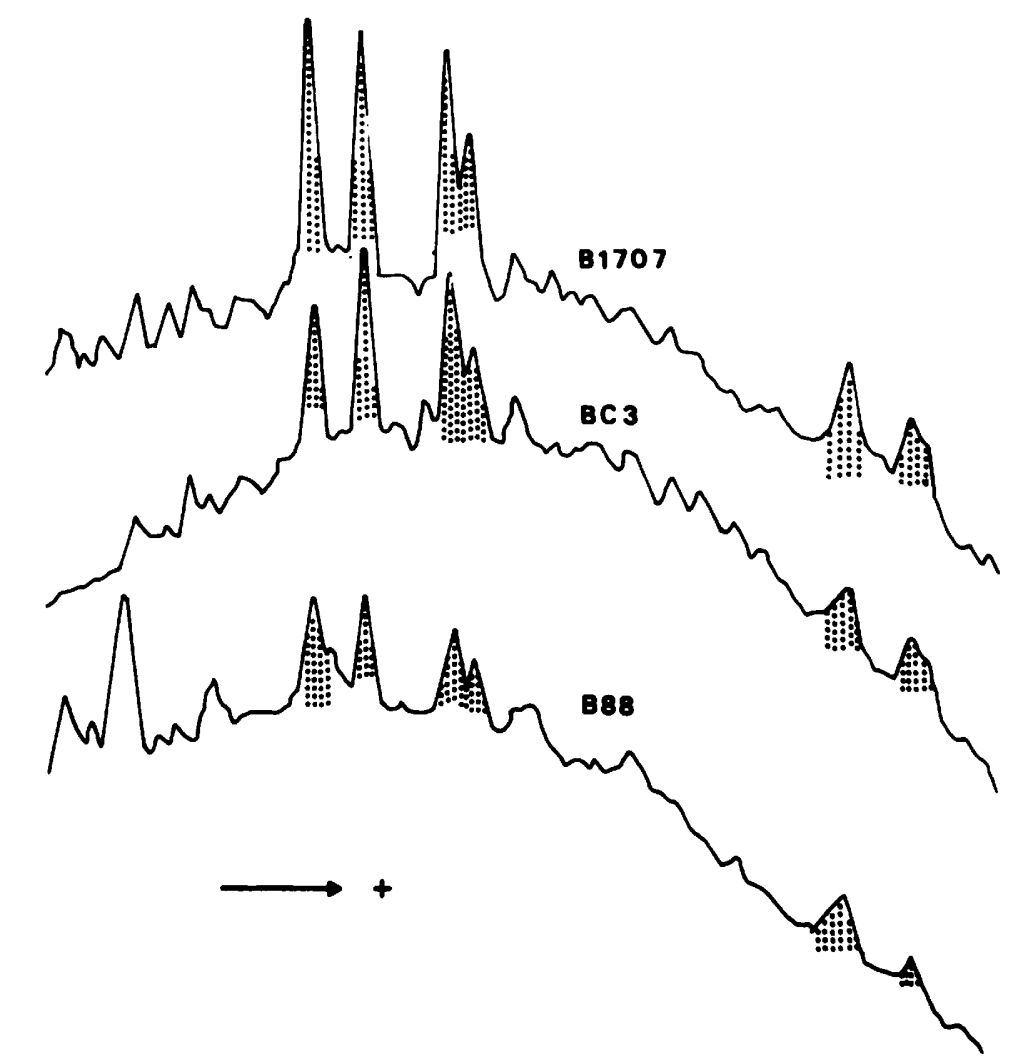

FIG. 5. Restriction enzyme $(E c o R I)$ profiles of subgroup $1-2$ strains $B C-3^{T}, B 1707$, and B88. These profiles are characteristic of the subgroup.

(SpV4), which plaqued only on lawns of subgroup I-2 spiroplasmas $(69,70)$.

Studies of strain BC- $3^{\mathrm{T}}$ have provided significant information on the evolution of the class Mollicutes. Recent development of cataloging techniques for $16 \mathrm{~S}$ ribosomal ribonucleic acid (36) have generated wide interest in the relationships among the higher taxa in the division. (Note that the name "Tenericutes" has recently been proposed for the division [41] of Procaryotae that comprises wall-less organisms [64].) Some of the results have been interpreted as indicating that the Spiroplasmataceae $(75,76)$ and the Acholeplasmataceae $(34,38)$ evolved along branches of sufficient depth that Tenericutes might be a polyphyletic taxon $(65,106)$. However, evidence obtained by Walker and colleagues (91) from sequencing of the $5 \mathrm{~S}$ ribosomal ribonucleic acid of strain $\mathrm{BC}-3^{\mathrm{T}}$ has shown that the acholeplasmas and spiroplasmas are more closely related to each other than to any walled bacterium.

Strain BC- $3^{\mathrm{T}}$ has been used in several studies concerning the relationship between structure and function in Spiroplasma. Daniels and colleagues used this strain in studies which demonstrated viscotactic behavior in viscocity gradients. Positive chemotactic responses towards sugars and some amino acids were observed, and negative responses toward hydrophobic amino acids, some organic acids, and heavy metals were observed $(25,26)$.

A possible basis for spiroplasma motility was discovered in 1974 by Williamson (98), who reported the presence of fibrils in preparations of lysed cells. In 1980, Townsend and colleagues partially purified fibrils from strain $\mathrm{BC}-3^{\mathrm{T}}(82)$. The released fibrils were $3.5 \mathrm{~nm}$ in diameter, with an axial repeat of $8.5 \mathrm{~nm}$. In $1 \mathrm{M} \mathrm{NaCl}$, the released fibrils formed aggregates having a marked striated appearance. They were composed of a single protein having a molecular weight of 55,000 and represented about $1 \%$ of the total cell protein. Purification of the fibril protein led to the development of an antiserum that appeared to be specific to Spiroplasma (81) and was thought to provide a simple test for genus (or family) membership. This antiserum was used $(80)$ to demonstrate the absence of strain $\mathrm{BC}-3^{\mathrm{T}}$ fibrillar protein in the tissues of plants infected with eight agents of "yellows" diseases, infections that are thought to be induced by nonhelical mycoplasma-like organisms. Recently, Williamson et al. (99) were unable to demonstrate the presence of the fibrillar protein in group VI spiroplasmas. In light of the other unusual properties of group VI spiroplasmas (86), the significance of these findings is unclear.

Finally, strain $\mathrm{BC}-3^{\mathrm{T}}$ has been used in studies of spiroplasma pathogenicity. This strain and $S$. apis have provided the major examples of significant spiroplasma pathogenesis for insects in nature; therefore, strain $\mathrm{BC}-3^{\mathrm{T}}$ has been used in in vitro studies of pathogenic interactions. McCoy and colleagues showed (57) that this organism multiplied, as did many other spiroplasmas, in the greater wax moth (Galleria mellonella). Steiner et al. used this organism to study replication and cell interaction in the Drosophila Dm-1 cell line (78). In these studies, a high level of uridine phosphorylase activity of the cultured organisms was demonstrated. Possible pathogenicity of strain $B C-3^{T}$ to embryonated chicken eggs and rodents was studied by Tully (84).

Additional information on subgroup I-2 spiroplasmas is available from studies concerning strain AS 576. Strain AS 576 was isolated from an infected bee collection from the 
same apiary that produced strain $\mathrm{BC}-3^{\mathrm{T}}$; its authenticity as a subgroup I-2 member was confirmed by growth inhibition tests (94) and by the serological results presented in this report. Also, certain characterization results with strain AS 576 reported briefly in abstract form (R. E. Davis, Proc. Am. Phytopathol. Soc. 3:304, 1976) are similar to those reported here for strain $\mathrm{BC}-3^{\mathrm{T}}$.

The viscotactic response of strain AS 576 was demonstrated in 1980 by Berenstein and Doetsch (4), and the effect of osmotic pressure on this organism has been studied by Liao and colleagues (51). The genome molecular weight of strain AS 576 was determined to be about $10^{9}$, and the $\mathrm{G}+\mathrm{C}$ content of its DNA was about $26 \mathrm{~mol} \%$ (48). The antibiotic susceptibilities of strain AS 576 have been studied by two groups of workers. Liao and Chen (50) showed that the aminoglycoside antibiotics that contain a deoxystreptamine moiety (kanamycin, neomycin, and gentamicin) are effective, whereas those that lack this moiety (e.g., kasugamycin, hygromycin and spectinomycin) are not. Strains permanently resistant to some of the antibiotics were selected by Liao and Chen (50). Davis (27) obtained similar spectra for eight isolates of subgroup I-2, including strain AS 576; strain $\mathrm{BC}-3^{\mathrm{T}}$ was not included in these tests.

Perhaps the most important studies concerning strain AS 576 have been those of Chang and Chen, who adapted this strain to grow to a concentration of about $3 \times 10^{9}$ cells per $\mathrm{ml}$ in a chemically defined medium (CC-494 medium) (13). Subsequently, these workers evaluated some of the metabolic capabilities of strain AS 576 growing in CC-494 medium $(12,14)$. Glucose, fructose, and mannose were utilized by strain AS 576 and by representative strains of $S$. floricola and $S$. apis. Strain AS 576 fermented trehalose and required at least one purine base and one pyrimidine base for growth, whereas the other spiroplasmas grew in the presence of either single base in the medium. Oleic acid, cholesterol, and bovine serum albumin were essential to the growth of all of the spiroplasmas.

Together, the properties described in this paper and those described in previously published studies on subgroup I-2 spiroplasmas provide an exceptionally well-detailed biological and molecular characterization of the in vitro properties of strain $\mathrm{BC}-3^{\mathrm{T}}$ and related strains. A considerable amount of knowledge concerning the natural ecology of these organisms is also available.

After the discovery of strain $\mathrm{BC}-3^{\mathrm{T}}$ and related strains, a search for a seasonal source of honeybee infections was initiated. This search led to the discovery of spiroplasmas on plant surfaces (16) and, as a result, to the discovery of their widespread occurrence in insects (18). Although there are gaps in our knowledge of the ecology of the honeybee spiroplasma (particularly with reference to overwintering), some features of its natural ecology are known. For example, we know that honeybees are not the only insect host of subgroup I-2 spiroplasmas. Since the discovery of the subgroup I-2 spiroplasma in honeybees, additional isolates have been obtained from representatives of three major orders of insects (Hymenoptera, Diptera, and Lepidoptera). Subgroup I-2 spiroplasmas were cultured from the hemolymph of bumblebees (Bombus impatiens) in June and July 1979 (4 of 392 insects sampled), leafcutter bees (Osmia cornifrons) in May 1983 (all 20 samples), and a single unidentified robber fly (Diptera: Asilidae), a $20-\mathrm{mm}$ predacious bee mimic that was captured with a honeybee in its mouth in July 1982. Additionally, isolates were obtained from the intestines of bumblebees (Bombus pennsylvanicus) in May 1982 (6 of 7 insects sampled), unidentified andrenid bees in May 1983 ( 2 of 7 insects sampled), digger bees (Anthophora abrupta) in June 1983 (2 of 23 samples), and an unidentified swallowtail butterfly (probably either a spicebush or dark tiger swallowtail) in May 1983. It now appears that isolations of subgroup I-2 spiroplasmas from flowers (66) represent fecal contaminations from infected insect hosts.

The degree or form of pathogenicity (if any) of subgroup I-2 spiroplasmas in these additional insect hosts has not been determined yet, but the concentrations of spiroplasmas in the hemolymph of these species were comparable to the concentrations in the hemolymph of honeybees that later died from their infections. Although the occurrence of subgroup I-2 spiroplasmas in the intestines of some insects may represent mere accidental infections, the intestinal phase does play an important role in honeybee infections. Also, insect intestine is known to be the normal habitat of certain spiroplasmas $(19,20)$. It is evident that a variety of insects, all of which are either directly or indirectly associated with the floral habitat, are capable of disseminating the subgroup I-2 spiroplasmas and may play important roles in their maintenance in nature. Fortunately for the honeybee industry and agriculture in general, there is no evidence to support the concept that the honeybee spiroplasma can multiply either in plants or on plant surfaces.

Strain $\mathrm{BC}-3^{\mathrm{T}}$ and related spiroplasmas from honeybees and other insects have been shown to be members of the Mollicutes (33) and to be referable to the family Spiroplasmataceae $(75,76)$ and to the genus Spiroplasma (71). We propose that these organisms be designated Spiroplasma melliferum sp. nov. The taxonomic description given below summarizes the properties of this organism.

Spiroplasma melliferum sp. nov. Spiroplasma melliferum (mel.lif.'er.um.M.L.adj.melliferum specific epithet of the honeybee [Apis mellifera], referring to the insect host) cells are pleomorphic, varying from helical filaments that are 100 to $150 \mathrm{~nm}$ in diameter and 3 to $10 \mu \mathrm{m}$ long to nonhelical filaments or spherical cells that are 300 to $800 \mathrm{~nm}$ in diameter. Cells lack true cell walls and periplasmic fibrils. Motile. Colonies on solid medium supplemented with $0.8 \%$ Noble agar are usually diffuse, rarely exhibiting central zones of growth into agar. Colonies on solid medium containing $2.25 \%$ Noble agar are smaller, but frequently have a fried egg morphology. Chemoorganotroph. Acid produced from glucose and mannose. Hydrolyzes arginine. Does not hydrolyze urea. Reduction of tetrazolium variable. Phosphatase negative. Film and spot reaction positive. No liquefaction of coagulated serum. Agar colonies do not hemadsorb guinea pig erythrocytes.

Cholesterol required for growth.

Facultative anaerobe.

Temperature range, 20 to $37^{\circ} \mathrm{C}$; temperature optimum, 32 to $35^{\circ} \mathrm{C}$.

Isolated from hemolymph and gut of honeybees $(A$. mellifera) in widely separated geographic regions. Also recovered from hemolymph of bumble bees, leafcutter bees, and a robber fly and the intestinal contents of sweat bees, digger bees, bumblebees, and a butterfly. Pathogenic for honeybees in natural and experimental oral infections. Also recovered from a variety of plant surfaces (flowers) in widely separated geographic regions.

The $\mathrm{G}+\mathrm{C}$ content of the DNA is $26 \mathrm{~mol} \%$ as determined by the melting temperature method and 27 to $28 \mathrm{~mol} \%$ as determined by the buoyant density method. The genome molecular weight: is $10^{9}$.

Type strain: strain BC-3 (= ATCC 33219). 


\section{ACKNOWLEDGMENTS}

We thank C. Blood, J.-C. Vignault, E. Clark, and K. Hackett for assistance in various parts of this study. We also thank S. EdenGreen and P. Saglio for furnishing strains for the study.

\section{LITERATURE CITED}

1. Aluotto, B. B., R. G. Wittler, C. O. Williams, and J. E. Faber. 1970. Standardized bacteriologic techniques for the characterization of Mycoplasma species. Int. J. Syst. Bacteriol. 20:35-58.

2. Archer, D. B., and J. Best. 1980. Serological relatedness of spiroplasmas estimated by enzyme-linked immunosorbent assay and crossed immunoelectrophoresis. J. Gen. Microbiol. 119:413-422.

3. Archer, D. B., and R. Townsend. 1981. Immunoelectrophoretic separation of spiroplasma antigens. J. Gen. Microbiol. 123: 61-68.

4. Berenstein, E., and R. N. Doetsch. 1980. On the motility of Spiroplasma sp. AS 576. Microbios 15:77-81.

5. Bové, J. M., C. Mouches, P. Carle-Junca, J. R. DegorceDumas, J. G. Tully, and R. F. Whitcomb. 1983. Spiroplasmas of Group I. The Spiroplasma citri cluster. Yale J. Biol. Med. 56:573-582.

6. Bové, J. M., and C. Saillard. 1979. Cell biology of spiroplasmas, p. 83-153. In R. F. Whitcomb and J. G. Tully (ed.), The mycoplasmas, vol. 3. Academic Press, Inc., New York.

7. Bové, J. M., C. Saillard, P. Junca, J. R. Degorce-Dumas, B. Ricard, A. Nhami, R. F. Whitcomb, D. L. Williamson, and J. G. Tully. 1982. Guanine-plus-cytosine content, hybridization percentages, and EcoRI restriction enzyme profiles of spiroplasmal DNA. Rev. Infect. Dis. 4(Suppl.):S129-S136.

8. Bradbury, J. M. 1977. Rapid biochemical tests for characterization of the Mycoplasmatales. J. Clin. Microbiol. 5:531-534.

9. Brinton, L. P., and W. Burgdorfer. 1976. Cellular and subcellular organization of the $277 \mathrm{~F}$ agent, a spiroplasma from the rabbit tick, Haemaphysalis leporispalustris (Acari: Ixodidae). Int. J. Syst. Bacteriol. 26:554-560.

10. Carle, P., C. Saillard, and J. M. Bové. 1983. DNA extraction and purification, p. 295-299. In S. Razin and J. G. Tully (ed.), Methods in mycoplasmology, vol. 1. Academic Press, Inc., New York.

11. Carle, P., C. Saillard, and J. M. Bové. 1983. Determination of guanine plus cytosine content of DNA, p. 301-308. In S. Razin and J. G. Tully (ed.), Methods in mycoplasmology, vol. 1. Academic Press, Inc., New York.

12. Chang, C.-J. 1984. Vitamin requirements of three spiroplasmas. J. Bacteriol. 160:488-490.

13. Chang, C.-J., and T. A. Chen. 1982. Spiroplasmas: cultivation in chemically defined medium. Science 215:1121-1122.

14. Chang, C.-J., and T. A. Chen. 1983. Nutritional requirements of two flower spiroplasmas and honeybee spiroplasma. J. Bacteriol. 153:452-457.

15. Chen, T. A., and C. H. Liao. 1975. Corn stunt spiroplasma: isolation, cultivation and proof of pathogenicity. Science 188:1015-1017.

16. Clark, T. B. 1977. Spiroplasma sp., a new pathogen in honeybees. J. Invertebr. Pathol, 29:112-113.

17. Clark, T. B. 1978 . Honey bee spiroplasmosis, a new problem for beekeepers. Am. Bee J. 118:18-19, 23.

18. Clark, T. B. 1982. Spiroplasmas: diversity of arthropod reservoirs and host-parasite relationships. Science 217:57-59.

19. Clark, T. B., and R. F. Whitcomb. 1983. Special procedures for demonstration of mycoplasmal pathogenicity in insects, $\mathrm{p}$. 369-379. In J. G. Tully and S. Razin (ed.), Methods in mycoplasmology, vol. 2. Academic Press, Inc., New York.

20. Clark, T. B., R. F. Whitcomb, and J. G. Tully. 1982. Spiroplasmas from coleopterous insects: new ecological dimensions. Microb. Ecol. 8:401-409.

21. Clyde, W. A., Jr. 1964. Mycoplasma species identification based upon growth inhibition by specific antisera. J. Immunol.
92:958-965.

22. Cole, R. M., J. G. Tully, T. J. Popkin, and J. M. Bové. 1973. Ultrastructure of the agent of citrus "stubborn disease." J. Bacteriol. 115:367-386.

23. Coomaraswamy, U., and D. J. Gumpf. 1984. Immuno-doublediffusion serological relationships among spiroplasma isolates. Int. J. Syst. Bacteriol. 34:173-176.

24. Daniels, M. J., D. B. Archer, M. A. Stephens, R. Townsend, J. M. Longland, and J. Best. 1980. Comparison of spiroplasmas by polyacrylamide gel electrophoresis of cell proteins. Curr. Microbiol. 4:377-380.

25. Daniels, M. J., and J. M. Longland. 1984. Chemotactic behavior of spiroplasmas. Curr. Microbiol. 10:191-193.

26. Daniels, M. J., J. M. Longland, and J. Gilbart. 1980. Aspects of motility and chemotaxis in spiroplasmas. J. Gen. Microbiol. 118:429-436.

27. Davis, R. E. 1981. Antibiotic sensitivities in vitro of diverse spiroplasma strains associated with plants and insects. Appl. Environ. Microbiol. 41:329-333.

28. Davis, R. E., and I.-M. Lee. 1982. Comparative properties of spiroplasmas and emerging taxonomic concepts: a proposal. Rev. Infect. Dis. 4 (Suppl.): S122-S128.

29. Davis, R. E., I.-M. Lee, and L. K. Basciano. 1979. Spiroplasmas: serological grouping of strains associated with plants and insects. Can. J. Microbiol. 25:861-866.

30. Davis, R. E., I.-M. Lee, and J. F. Worley. 1981. Spiroplasma floricola, a new species isolated from surfaces of flowers of the tulip tree, Liriodendron tulipifera L. Int. J. Syst. Bacteriol. 31:456-464.

31. Eden-Green, S. J., and H. Waters. 1981. Isolation and preliminary characterization of a spiroplasma from coconut palms in Jamaica. J. Gen. Microbiol. 124:263-270.

32. Edward, D. G. ff. 1947. A selective medium for pleuropneumonia-like organisms. J. Gen. Microbiol. 1:238-243.

33. Edward, D. G. ff., and E. A. Freundt. 1967. Proposal for Mollicutes as name of the class established for the order Mycoplasmatales. Int. J. Syst. Bacteriol. 17:267-268.

34. Edward, D. G. ff., and E. A. Freundt. 1970. Amended nomenclature for strains related to Mycoplasma laidlawii. J. Gen. Microbiol. 62:1-2.

35. Fabricant, J., and E. A. Freundt. 1967. Importance of extension and standardization of laboratory tests for the identification and classification of mycoplasmas. Ann. N.Y. Acad. Sci. 143:50-58.

36. Fox, G. E., E. Stackebrandt, R. B. Hespell, J. Gibson, J. Maniloff, T. A. Dyer, R. S. Wolfe, W. E. Balch, R. S. Tanner, L. J. Magrum, L. B. Zablen, R. Blakemore, R. Gupta, L. Bonen, B. J. Lewis, D. A. Stahl, K. R. Luehrsen, K. N. Chen, and C. R. Woese. 1980. The phylogeny of prokaryotes. Science 209:457-463.

37. Freundt, E. A., B. E. Andrews, H. Ernø, M. Kunze, and F. T. Black. 1973. The sensitivity of Mycoplasmatales to sodiumpolyanethol-sulfonate and digitonin. Zentralbl. Bakteriol. Parasitenkd. Infektionskr. Hyg. Abt. 1 Orig. Reihe A 225:104-112

38. Freundt, E. A., R. F. Whitcomb, M. F. Barile, S. Razin, and J. G. Tully. 1984. Proposal for elevation of the family Acholeplasmataceae to ordinal rank: Acholeplasmatales. Int. J. Syst. Bacteriol. 34:346-349.

39. Fudl-Allah, A.-E. A., E. C. Calavan, and E. C. K. Igwegbe. 1972. Culture of a mycoplasmalike organism associated with stubborn disease of citrus. Phytopathology 62:729-731.

40. Garnier, M., M. Clerc, and J. M. Bové. 1981. Growth and division of spiroplasmas: morphology of Spiroplasma citri during growth in liquid medium. J. Bacteriol. 147:642-652.

41. Gibbons, N. E., and R. G. E. Murray. 1978. Proposals concerning the higher taxa of bacteria. Int. J. Syst. Bacteriol. 28:1-6.

42. International Committee on Systematic Bacteriology Subcommittee on the Taxonomy of Mollicutes. 1979. Proposal of minimal standards for descriptions of new species of the class Mollicutes. Int. J. Syst. Bacteriol. 29:172-180.

43. International Committee on Systematic Bacteriology Subcommittee on the Taxonomy of Mollicutes. 1982. Minutes of the 
meeting, 27 and 30 August and 5 September 1978, Freiburg and Munich, F.R.G. Int. J. Syst. Bacteriol. 32:261-264.

44. International Committee on Systematic Bacteriology Subcommittee on the Taxonomy of Mollicutes. 1984. Minutes of interim meetings, 2 and 5 September 1980, Custer, South Dakota. Int. J. Syst. Bacteriol. 34:358-360.

45. International Committee on Systematic Bacteriology Subcommittee on the Taxonomy of Mollicutes. 1984. Minutes of the interim meeting, 30 August and 6 September 1982, Tokyo, Japan. Int. J. Syst. Bacteriol. 34:361-365.

46. Jones A. L., R. F. Whitcomb, D. L. Williamson, and M. E. Coan. 1977. Comparative growth and primary isolation of spiroplasmas in media based on insect tissue culture formulations. Phytopathology 67:738-746.

47. Junca, P., C. Saillard, J. G. Tully, O. Garcia-Jurado, J. R. Degorce-Dumas, C. Mouches, J. C. Vignault, R. Vogel, R. McCoy, R. Whitcomb, D. Williamson, J. Latrille, and J. M. Bové. 1980. Charactérisation de spiroplasmes isolés d'insectes et de fleurs de France continentale, de Corse et du Maroc. Proposition pour une classification des spiroplasmes. C. R. Acad. Sci. Ser. D 290:1209-1212.

48. Lee, I.-M., and R. E. Davis. 1980. DNA homology among diverse spiroplasma strains representing several serological groups. Can. J. Microbiol. 26:1356-1363.

49. Lei, J. D., H. J. Su, and T. A. Chen. 1979. Spiroplasmas isolated from green leaf bug, Trigonotylus ruficornis Geoffroy, p. 89-97. In H. J. Su and R. E. McCoy (ed.), Proceedings of the Republic of China-United States Cooperative Science Seminar on Mycoplasma Diseases of Plants. National Science Council Symposium Series, vol. 1. National Science Council, Taipei.

50. Liao, C. H., and T. A. Chen. 1981. In vitro susceptibility and resistance of two spiroplasmas to antibiotics. Phytopathology 71:442-445.

51. Liao, C. H., P. J. Cotty, and T. A. Chen. 1979. Osmostability of plant and insect spiroplasmas, p. 83-87. In H. J. Su and R. E. McCoy (ed.), Proceedings of the Republic of ChinaUnited States Cooperative Science Seminar on Mycoplasma Diseases of Plants. National Science Council Symposium Series, vol. 1. National Science Council, Taipei.

52. Liss, A., and R. M. Cole. 1981. Spiroplasmavirus group 1: isolation, growth and properties. Curr. Microbiol. 5:357-362.

53. Liss, A., and R. M Cole. 1982. Spiroplasmaviruses: group 1 characteristics. Rev. Infect. Dis. 4(Suppl.):S115-S119.

54. Manchee, R. J., and D. Taylor-Robinson. 1968. Haemadsorption and hemagglutination by mycoplasmas. J. Gen. Microbiol. 50:465-478.

55. Markham, P., T. B. Clark, and R. F. Whitcomb. 1983. Culture techniques for spiroplasmas from arthropods, p. 217-223. In J. G. Tully and S. Razin (ed.), Methods in mycoplasmology, vol. 2. Academic Press, Inc., New York.

56. McCoy, R. E., H. G. Basham and R. E. Davis. 1982. Powder puff spiroplasma: a new epiphytic mycoplasma. Microb. Ecol. 8:169-180.

57. McCoy, R. E., M. J. Davis, and R. V. Dowell. 1981. In vivo multiplication of spiroplasmas in larvae of the greater wax moth. Phytopathology 71:408-411.

58. Mouches, C., and J. M. Bové. 1983. Electrophoretic characterization of mycoplasma proteins, p. 241-255. In S. Razin and J. G. Tully (ed.), Methods in mycoplasmology, vol. 1. Academic Press, Inc., New York.

59. Mouches, C., J. M. Bové, J. Albisetti, T. B. Clark, and J. G. Tully. 1982. A spiroplasma of serogroup IV causes a Maydisease-like disorder of honeybees in southwestern France. Microb. Ecol. 8:387-399.

60. Mouches, C., J. M. Bové, J. G. Tully, D. L. Rose, R. E. McCoy, P. Carle-Junca, M. Garnier, and C. Saillard. 1983. Spiroplasma apis, a new species from the honey-bee (Apis mellifera). Ann. Inst. Microbiol. (Inst. Pasteur) 134A:383-397.

61. Mouches, C., P. Duthil, J.-C. Vignault, F. Protopapadakis, A. Nhami, J. G. Tully, and J. M. Bové. 1980. Characterization of spiroplasmas by polyacrylamide gel analysis of their proteins and enzymes, p. 133-144. In E. C. Calavan, S. M. Garnsey, and L. W. Timmer (ed.), Proceedings of the 8th Conference of the International Organization of Citrus Virologists. University of California Press, Riverside.

62. Mouches, C., A. Menara, J. G. Tully, and J. M. Bové. 1982. Polyacrylamide gel analysis of spiroplasmal proteins and its contribution to the taxonomy of spiroplasmas. Rev. Infect. Dis. 4:(Suppl.):S141-S147.

63. Mouches, C., J. C. Vignault, J. G. Tully, R. F. Whitcomb, and J. M. Bové. 1979. Characterization of spiroplasmas by oneand two-dimensional protein analysis on polyacrylamide slab gels. Curr. Microbiol. 2:69-74.

64. Murray, R. G. E. 1984. The higher taxa, or a place for everything. . . ?, p. 31-34, In N. R. Krieg and J. G. Holt (ed.), Bergey's manual of systematic bacteriology, vol. 1,9 th ed. The Williams \& Wilkens Co., Baltimore.

65. Neimark, H., and J. London. 1982. Origins of the mycoplasmas: sterol-nonrequiring mycoplasmas evolved from streptococci. J. Bacteriol. 150:1259-1265.

66. Raju, B. C., G. Nyland, T. Meikle, and A. H. Purcell. 1981. Helical, motile mycoplasmas associated with flowers and honeybees in California. Can. J. Microbiol. 27:249-253.

67. Razin, S., and J. G. Tully. 1970. Cholesterol requirement of mycoplasmas. J. Bacteriol. 102:306-310.

68. Razin, S., J. G. Tully, D. L. Rose, and M. F. Barile. 1983. DNA cleavage patterns as indicators of genotypic heterogeneity among strains of Acholeplasma and Mycoplasma species. J. Gen. Microbiol. 129:1935-1944.

69. Renaudin, J., M. C. Pascarel, M. Garnier, P. Carle-Junca, and J. M. Bové. 1984. SpV4, a new spiroplasma virus with circular, single-stranded DNA. Ann. Virol. (Inst. Pasteur) 135E:343-361.

70. Renaudin, J., M. C. Pascarel, M. Garnier, P. Carle, and J. M. Bové. 1984. Characterization of spiroplasmavirus 4 (SV4). Isr. J. Med. Sci. 20:797-799.

71. Saglio, P., M. Lhospital, D. Laflèche, G. Dupont, J. M. Bové, J. G. Tully, and E. A. Freundt. 1973. Spiroplasma citri gen. and sp. n.: a mycoplasmalike organism associated with "stubborn" disease of citrus. Int. J. Syst. Bacteriol. 23:191-204.

72. Saillard, C., and J. M. Bové. 1983. EcoRI restriction enzyme analysis of mycoplasma DNA, p. 313-318. In S. Razin and J. G. Tully (ed.), Methods in mycoplasmology, vol. 1. Academic Press, Inc., New York.

73. Saillard, C., J. Dunez, O. Garcia-Jurado, A. Nhami, and J. M. Bové. 1978. Detection de Spiroplasma citri dans les agrumes et les pervenches par la technique immunoenzymatic (Elisa). C. R. Acad. Sci. 286:1245-1248.

74. Saillard, C., J. C. Vignault, A. Gadeau, P. Carle, M. Garnier, A. Fos, J. M. Bové, J. G. Tully, and R. F. Whitcomb. 1984. Discovery of a new plant-pathogenic spiroplasma. Isr. J. Med. Sci. 20:1013-1015.

75. Skripal, I. G. 1974. On improvement of taxonomy of the class Mollicutes and establishment in the order Mycoplasmatales of the new family Spiroplasmataceae Fam. Nova. Mikrobiol. Zh. (Kiev) 36:462-467.

76. Skripal, I. G. 1983. Revival of the name Spiroplasmataceae fam. nov., nom. rev., omitted from the 1980 Approved Lists of Bacterial Names. Int. J. Syst. Bacteriol. 33:408.

77. Stalheim, O. H. V., A. E. Ritchie, and R. F. Whitcomb. 1978. Cultivation, serology, ultrastructure, and virus-like particles of spiroplasma 277F. Curr. Microbiol. 1:365-370.

78. Steiner, T., G. J. McGarrity, and D. M. Phillips. 1982. Cultivation and partial characterization of spiroplasmas in cell cultures. Infect. Immun. 35:296-304.

79. Townsend, R. 1976. Arginine metabolism by Spiroplasma citri. J. Gen. Microbiol. 94:417-420.

80. Townsend, R. 1983. Mycoplasmalike organisms from plants with "yellows" diseases lack a spiroplasma-specific antigen. J. Gen. Microbiol. 129:1959-1964.

81. Townsend, R., and D. B. Archer. 1983. A fibril protein antigen specific to Spiroplasma. J. Gen. Microbiol. 129:199-206.

82. Townsend, R., D. B. Archer, and K. A. Plaskitt. 1980. Purification and preliminary characterization of spiroplasma fibrils. J. Bacteriol. 142:694-700.

83. Townsend, R., P. G. Markham, K. A. Plaskitt, and M. J. 
Daniels. 1977. Isolation and characterization of a non-helical strain of Spiroplasma citri. J. Gen. Microbiol. 100:15-21.

84. Tully, J. G. 1982. Interaction of spiroplasmas with plant, arthropod, and vertebrate hosts. Rev. Infect. Dis. 4(Suppl.):S193-S199.

85. Tully, J. G., D. L. Rose, O. Garcia-Jurado, J.-C. Vignault, C. Saillard, J. M. Bové, R. E. McCoy, and D. L. Wiliamson. 1980. Serological analysis of a new group of spiroplasmas. Curr. Microbiol. 3:369-372.

86. Tully, J. G., D. L. Rose, C. E. Yunker, J. Cory, R. F. Whitcomb, and D. L. Williamson. 1981. Helical mycoplasmas (spiroplasmas) from Ixodes ticks. Science 212:1043-1045.

87. Tully, J. G., R. F. Whitcomb, J. M. Bové, and P. Saglio. 1973. Plant mycoplasmas: serological relation between agents associated with citrus stubborn and corn stunt diseases. Science 182:827-829.

88. Tully, J. G., R. F. Whitcomb, H F. Clark, and D. L. Williamson. 1977. Pathogenic spiroplasmas: cultivation and vertebrate pathogenicity of a new spiroplasma. Science 195:892-894.

89. Tully, J. G., R. F. Whitcomb, D. L. Rose, and J. M. Bové. 1982. Spiroplasma mirum, a new species from the rabbit tick (Haemaphysalis leporispalustris). Int. J. Syst. Bacteriol. 32:92-100.

90. Vignault, J. C., J. M. Bové, C. Saillard, R. Vogel, A. Farro, L. Venegas, W. Stemmer, S. Aoki, R. McCoy, A. S. Al-Beldawi, M. Larue, o. Tuzcu, M. Ozsam, A. Nhami, M. Abassi, J. Bonfils, G. Moutous, A. Fos, F. Poutiers, and G. ViennotBourgin. 1980. Mise en culture de spiroplasmes à partir de matériel végétal et d'insectes provenant de pays circumméditerraneens et du Proche-Orient. C. R. Acad. Sci. Ser. D 290:775-778.

91. Walker, R. T., E. T. J. Chelton, M. W. Kilpatrick, M. J. Rogers, and J. Simmons. 1982. The nucleotide sequence of the 5S rRNA from Spiroplasma species BC-3 and Mycoplasma mycoides subsp. capri PG-3. Nucleic Acids Res. 10:6363-6367.

92. Whitcomb, R. F. 1983. Culture media for spiroplasmas, p. 147-158. In S. Razin and J. G. Tully (ed.), Methods in mycoplasmology, vol. 1. Academic Press, Inc., New York.

93. Whitcomb, R. F., T. B. Clark, J. G. Tully, T. A. Chen, and J. M. Bové. 1983. Serological classification of spiroplasmas: current status. Yale J. Biol. Med. 56:453-459.

94. Whitcomb, R. F., J. G. Tully, T. B. Clark, D. L. Williamson, and J. M. Bové. 1982. Revised serological classification of spiroplasmas, new provisional groups, and recommendations for serotyping of isolates. Curr. Microbiol. 7:291-296.
95. Whitcomb, R. F., J. G. Tully, P. McCawley, and D. L. Rose. 1982. Application of the growth inhibition test to Spiroplasma taxonomy. Int. J. Syst. Bacteriol. 32:387-394.

96. Whitcomb, R. F., J. G. Tully, D. L. Rose, E. B. Stephens, A. Smith, R. E. McCoy, and M. F. Barile. 1982. Wall-less prokaryotes from fall flowers in central United States and Maryland. Curr. Microbiol. 7:285-290.

97. Whitcomb, R. F., J. G. Tully, and H. Wróblewski. 1983. Spiralin: major membrane protein specific for group I-1 spiroplasmas. Curr. Microbiol. 9:7-12.

98. Williamson, D. L. 1974. Unusual fibrils from the spirochete-like sex ratio organism. J. Bacteriol. 117:904-906.

99. Williamson, D. L., P. R. Brink, and G. W. Zieve. 1984. Spiroplasma fibrils. Isr. J. Med. Sci. 20:830-835.

100. Williamson, D. L., and D. F. Poulson. 1979. Sex ratio organisms (spiroplasmas of Drosophila), p. 175-208. In R. F. Whitcomb and J. G. Tully (ed.), The mycoplasmas, vol. 3. Academic Press, Inc., New York.

101. Williamson, D. L., and J. G. Tully. 1982. Characterization of spiroplasmas by serology. Rev. Infect. Dis. 4 (Suppl.):S137S140.

102. Williamson, D. L., J. G. Tully, and R. F. Whitcomb. 1979. Serological relationships of spiroplasmas as shown by combined deformation and metabolism inhibition tests. Int. J. Syst. Bacteriol. 29:345-351.

103. Williamson, D. L., and R. F. Whitcomb. 1974. Helical wall-free prokaryotes in Drosophila, leafhoppers and plants. Colloq. Inst. Natl. Sante Res. 33:283-290.

104. Williamson, D. L., and R. F. Whitcomb. 1975. Plant mycoplasmas: a cultivable spiroplasma causes corn stunt disease. Science 188:1018-1020.

105. Williamson, D. L., R. F. Whitcomb, and J. G. Tully. 1978. The spiroplasma deformation test, a new serological method. Curr. Microbiol. 1:203-207.

106. Woese, C. R., J. Maniloff, and L. B. Zablen. 1980. Phylogenetic analysis of the mycoplasmas. Proc. Natl. Acad. Sci. U.S.A. 77:494-498.

107. Wróblewski, H., K.-E. Johansson, and S. Hjertén. 1977. Purification and characterization of spiralin, the main protein of the Spiroplasma citri membrane. Biochim. Biophys. Acta 465:275-289.

108. Wróblewski, H., D. Robic, D. Thomas, and A. Blanchard. 1984. Comparison of the amino acid composition and antigenic properties of spiralins purified from the plasma membrane of different spiroplasmas. Ann. Inst. Pasteur Paris 135A:73-82. 